\title{
1 Analysis of the relationship between rainfall and economic growth in
}

2 Indian states

\section{Abstract}

5 The relationship between rainfall variability and economic growth is complex, and tends to

6 be significant in economies like India where agriculture plays a major role in economic

7 output and food security. This paper seeks to provide insight into this relationship using

8 Indian state-level economic and rainfall data from 1961-2012. We examine all 15 Indian

9 states with populations exceeding $20 \mathrm{~m}$, totalling $920 \mathrm{~m}$ people (as of 2000 ), about $12 \%$ of the

10 global population. Physical and human geography vary greatly between, and even within,

11 these states, reflecting the global range of water security challenges and providing an analogue for a range of global economic development and environmental conditions. We identify three patterns of interdependence between rainfall variability and economic growth: i) Continuous Correlation of rainfall and economic growth rates, ii) Decayed Correlation from a significant to an insignificant relationship, and iii) Never Correlated i.e. no significant observable correlation between rainfall and growth. Sensitivity to rainfall variability is somewhat less in wetter states. Investment in irrigation infrastructure has helped states to reduce their economic sensitivity to rainfall variability, with three of the four states that have Decayed Correlation of growth with rainfall having the highest percentage expansion in irrigated areas of the 15 states. Greater use of groundwater supplies (rather than surface water) does not, however, appear to influence the sensitivity of economic growth to rainfall variability. The relationship between rainfall-growth correlation and long term income is complex; states which are correlated generally appear to be growing faster than states which are not correlated, but that growth is occurring from a lower per capita income level. Finally, confirming national trends for India, the paper does not find that economic diversification away from agriculture has reduced economic sensitivity to rainfall variability. The observation that growth in economically-diversified states can still be dependent on rainfall invites further research into the ways in which rainfall either directly, or through other hydroclimatic variables, influences the general economy.

\section{Keywords:}

Rainfall Variability; Economic Growth, Irrigation, Water Security, Regression Modelling 


\section{Introduction}

2 Throughout modern history, India's economy has been thought to be strongly influenced by

3 variations in water resources on a seasonal and annual basis, estimated by some to account

4 for 45\% of fluctuations in inter-annual Gross Domestic Product (GDP) (Virmani 2004).

5 Significant work has been carried out examining the link between water resources and growth

6 at the national level (Gadgil and Gadgil, 2006, and Mooley et al.,1981), with attempts to

7 explain the propagation through the economy of the impacts of rainfall variation. The

8 challenges of ascribing causal mechanisms are highlighted by the literature, including the

9 paradox that the economy has continued to be sensitive to rainfall even while the national

10 economy has diversified away from agriculture, and the irrigated agricultural area has

11 expanded. At the state level, India exhibits significant geographic and climatic diversity, in addition to economic, cultural and political variation. Nonetheless, Indian states are governed by the Constitution of India, a common national framework that makes state-level data more amenable to comparison than country-level data used in previous studies of the relationship between hydroclimatic variability and economic growth (Hall et al., 2014). This paper examines the relationship between rainfall and economic growth across Indian states, revealing statically verifiable differences in behaviour, and deepening understanding of how water management may affect economic impact of changes in rainfall. In so doing, this paper extends the methodology and justification for examining rainfall-growth relationships. Section 1 of the paper reviews past empirical and conceptual work on rainfall-growth relationships, Section 2 reviews the economic and water resource development and rainfallgrowth relationships in India. Section 3 highlights research gaps and frames research hypotheses in light of the literature review. Section 4 discusses the data used in the analysis, with results and analysis presented in Section 5, followed by conclusions in Section 6.

Previous work has examined relationships between rainfall and growth (and/or agricultural output) at global or national scales, using a range of methodologies both to examine trends and investigate possible causal influences. The fundamental assumption behind this work is based on the premise that economies' growth can be influenced by rainfall and water availability (e.g. Brown et al., 2013), whereby droughts and floods impede agricultural, power and industrial production, and floods also impact physical infrastructure. At a country

32 level, this relationship is illustrated by Grey and Sadoff (2007) to be evident for Ethiopia over an 18 year period (Figure 1). Their work proposes that, for the period to 2000, Ethiopia's 
1 total and agricultural growth is influenced by annual rainfall. The years since 2000, not 2 included in Grey and Sadoff's analysis, have been relatively stable in terms of rainfall, and

3 also experienced significant economic growth, potentially removing the correlation with

4 rainfall that was observed up to the year 2000 (Conway and Schipper, 2011). However,

5 drought was still seen as a major risk (IMF 2014), which has been realised in 2016 (IMF

6 2016).

7

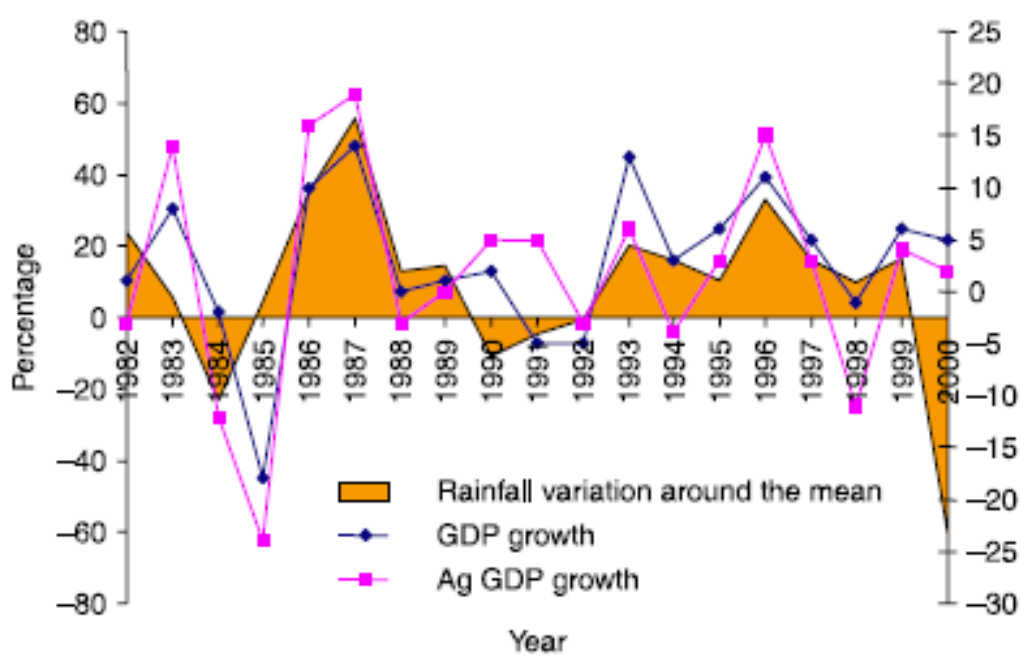

Figure 1 - Rainfall variation and Economic Growth for Ethiopia 1982-2000. From Grey and Sadoff 2007, Figure 5, developed from World Bank 2006, Figure ES.2

13 Building on work by Brown and Lall (2006) which comprised a global analysis of rainfallgrowth relationships, Sadoff et al. (2015) further highlights the strong relationship between trends in growth and water availability, in this case runoff, and suggest mechanisms by which growth has been buffered from the effects of inter-annual water resource availability. They conclude that the economic impact of rainfall variability (i.e. a form of water insecurity) poses a significant drag on long-term economic growth and development potential. It has been further argued that investment in infrastructure and institutions is associated with reduction in the negative impacts of variability on economic growth (Grey and Sadoff, 2006). Sadoff et al. (2015) presented three cases to illustrate different versions of the interrelationship between hydrological variability (as indicated by runoff) and growth (Figure 2): (i) Malawi is presented as a case of low investment and low water security, with a continuous sensitivity of growth to runoff variation; (ii) India is presented as a case of medium 
1 investment and reduced sensitivity of economic growth to runoff; and (iii) China, with high

2 investment in water (both storage and flood control), is seen to have eliminated the sensitivity

3 of growth to inter-annual runoff variability. The three countries fit on to an 'S' curve of

4 investment and water insecurity presented by Grey and Sadoff (2007), whereby cumulative

5 investment in water security measures enable countries to transition via a tipping point from

6 water insecure to water secure states. Dadson et al., (2017) take the process further,

7 conceptualising instances of investment as a promoter of growth and other cases where

8 insufficient or poor investment further drags the economy, resulting in a low-level

9 equilibrium trap. In this low-level trap, economies suffer recurrent losses and are not able to accumulate enough wealth to invest in water security.
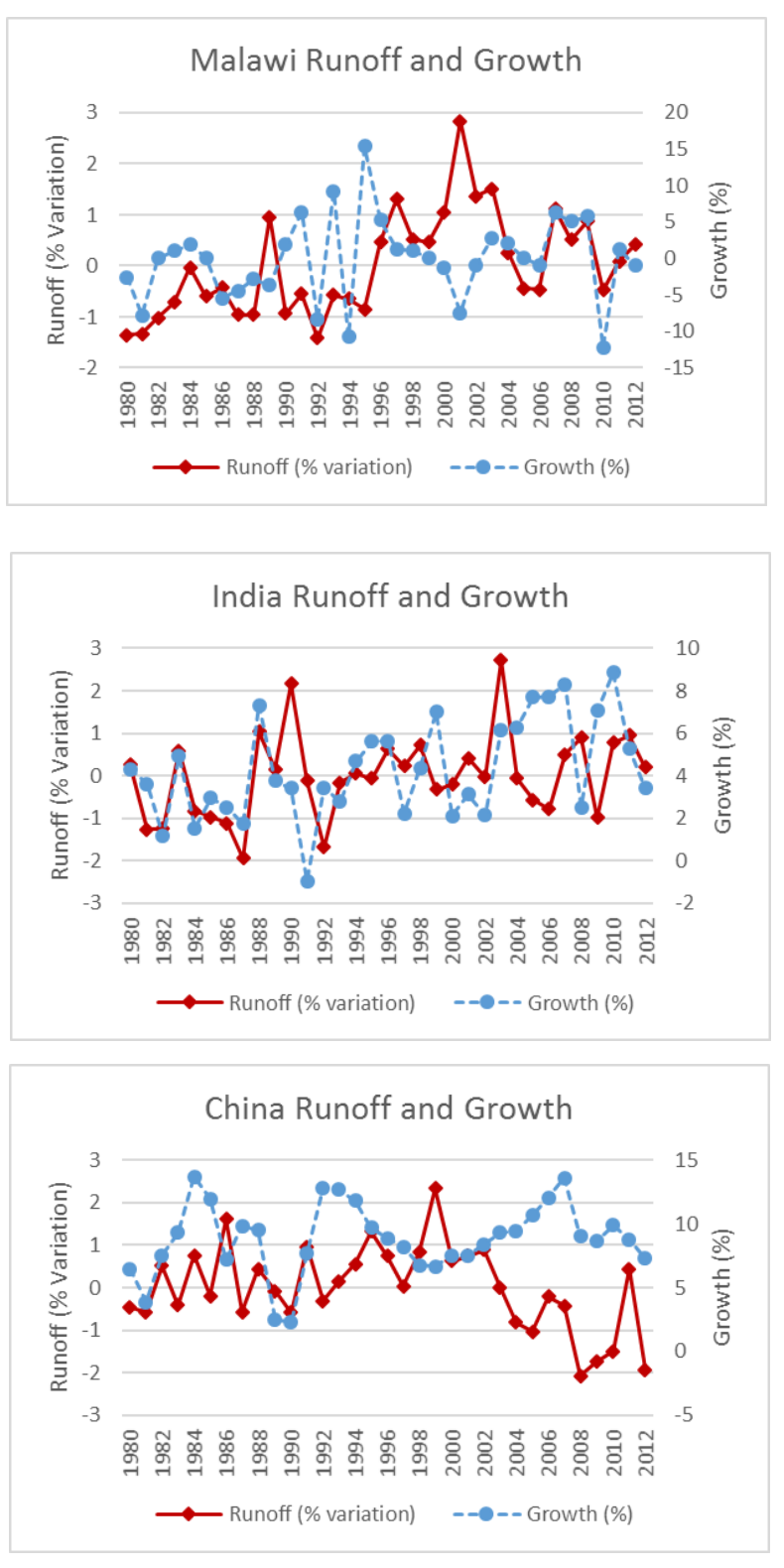
Figure 2 - Runoff variation (\%) and annual growth (\%) for Malawi (low investment, low water security), India (medium investment, medium water security) and China (high investment, high water security, growth no longer correlated with runoff variability). Adapted from Sadoff et al., 2015, box 2, data pers. comm.

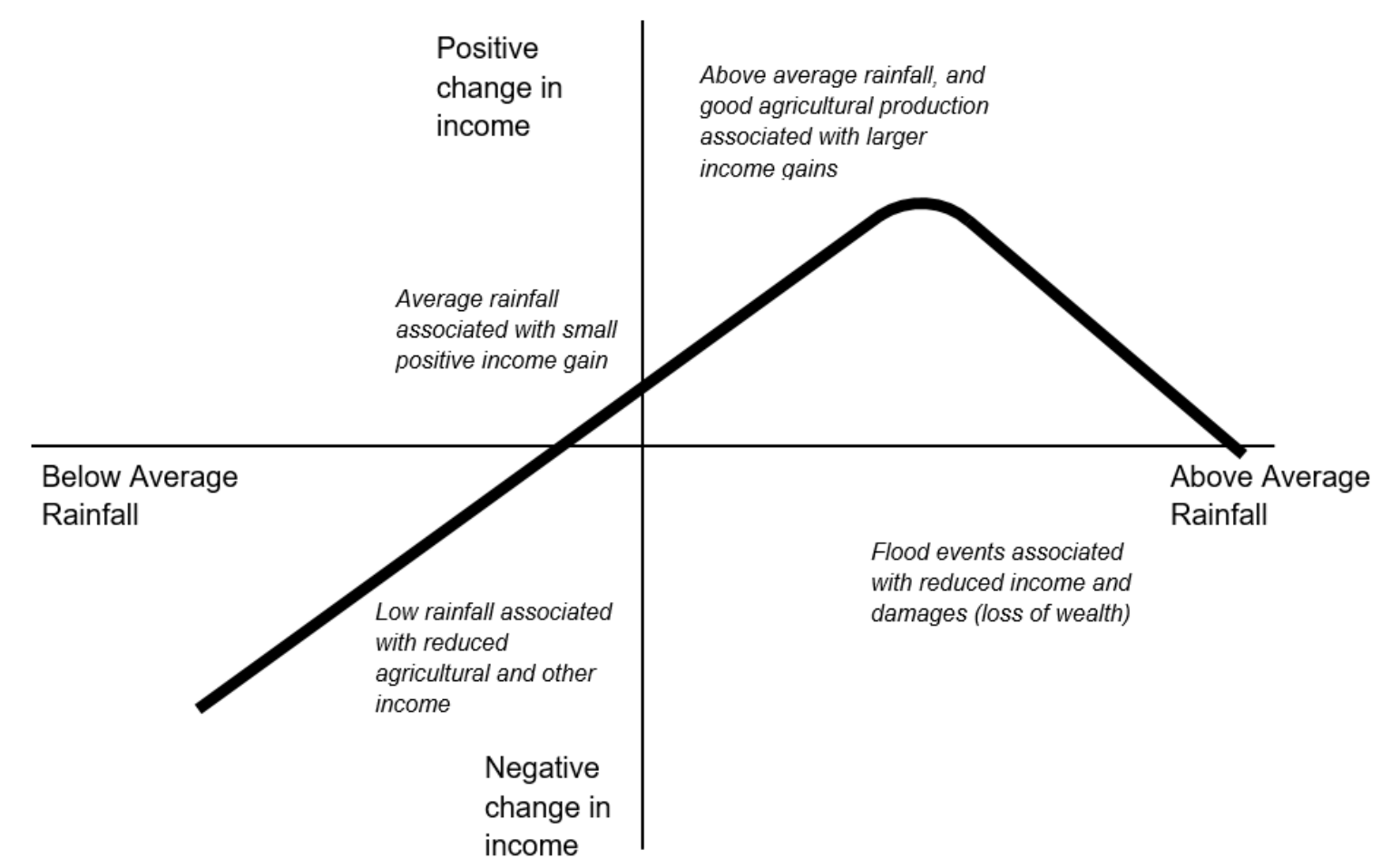

Figure 3 - Conceptual model of rainfall-growth sensitivity, whereby below average rainfall is associated with negative income change, moderately above average rainfall associated with positive income changes, and heavy rainfall (with flooding) associated with diminished income due to damage and economic disruption.

13 This growing body of literature has established hypotheses about the relationship between

14 hydroclimatic variability, water security and economic growth (changes in income) at national level, which is conceptualised in Figure 3. The model captures the ideas from Dadson et al (2017), that low rainfall (drought) will restrict agricultural and other production, and result in reduced income. Slightly below average rainfall can be tolerated, and can produce positive income, while moderately above average rainfall produces enhanced production and income. Extreme rainfall can produce floods that negatively impact income through lost crops, impacted communication and trade, and also result in damage to assets, captured in the model by a decline in income with large rainfall events. Water-related investments can help economies buffer themselves from low or high rainfall extremes

23 (Dadson et al. 2017). However, the rainfall-economy relationship can also be influenced by 
1 non-climatic factors, including social, economic, legal and political factors within and 2 between nations.

4 In large and geographically diverse countries, there is also a potential mismatch between the country-level at which statistical analyses have taken place and the complex sub-national scale processes through which causal influence is actually played out. There are many ways in which hydroclimatic variability may influence the behaviour of economic agents, alongside many other non-climatic factors. In an attempt to bridge these gaps, this paper analyses state-level data in India in order to provide a first national, inter-state analysis of the relationship between rainfall and growth, and provide a comparative base to examine potential causal mechanisms behind the relationships. The rationale for an inter-state water security analysis in India are outlined by Briscoe et al. (2005). We recognise that state-level data are still at a high level of aggregation, but argue that operating at a state level within one country helps to address some of the factors that confound cross-country comparisons. We seek to understand changes in relationship between rainfall and growth sensitivity over time, including the role of widespread expansion of irrigation in India, the uptake of tubewells from the 1960s that spurred individual irrigation enterprises, and the economic reforms of the 1980s and 1990s. In all, India’s fifteen largest states are analysed.

\section{Hydroclimatic variability and economic development in India}

India is home to the world's second largest national population. It is almost entirely dependent on internal food production, with only 1.3\% of its food tonnage imported in 2011 (FAO 2013). The country exhibits significant geographic diversity, ranging from subtropical, tropical, alpine and semi-arid to desert environments, with associated human settlement patterns and economic conditions, and with a high degree of intra- and interannual rainfall variability driven by the eastern and western branches of the South Asian monsoon system. Therefore an aggregated national analysis of the relationship between rainfall and growth can present a very different picture to the relationship seen in individual states (Dreze and Sen 2013). A more granular analysis at the state-level can help illuminate sub-national heterogeneity and potentially further identify factors contributing to any emergent trends. 
1 Due to this geographic diversity, India spans many of the human and environmental contexts,

2 and thus water security challenges, seen across the world. The country also exhibits significant economic diversity, from state economies dominated by pastoralism and agriculture to those increasingly built on industry and services. The states are politically and spatially heterogeneous. Spanning capitalist and socialist philosophies, they exhibit a near 5fold difference in per-capita income between the poorest and richest states, and there are large differences in territorial extent between the smallest and largest states. In this study, all states with populations over 20 million (or greater than $2 \%$ of national population) have been selected, encompassing fifteen of India's 29 states and 7 union territories. This filter ensures that the smallest states and directly-ruled union territories, are excluded from the analysis, in order to control for one element of economic and political heterogeneity in the cross-state comparison. The 15 states comprise 920 million people as of $2000,88 \%$ of the national population, and $12 \%$ of the global population. The year 2000 was chosen as the reference population year, as this predates the split of Bihar, Madhya Pradesh and Uttar Pradesh, and also enables jurisdictionally consistent comparison of economic growth across time later in the paper. The diversity of key geographic and economic characteristics are shown in Table 1. The table illustrates the considerable variation in personal income between states, as expressed by Net State Domestic Product (NSDP) per capita, and the range of relative growth between different states during the period 1970-2000, ranging from close to zero (Madhya Pradesh) to over $400 \%$ (Haryana). In all states the importance of agriculture declined between 1970 and 2005, however the relative importance of agriculture varies between economies from 13 to $36 \%$. Average state rainfall varies from $441 \mathrm{~mm} / \mathrm{yr}$ in Rajasthan to $2828 \mathrm{~mm} / \mathrm{yr}$ in Kerala. This national environmental, and economic diversity also provides India with considerable ability to learn from the diversity of its own experience (Dreze and Sen 2013). 


\begin{tabular}{|c|c|c|c|c|c|c|c|c|c|c|}
\hline State & 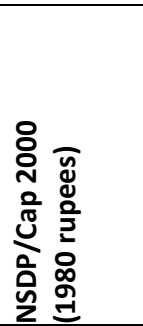 & 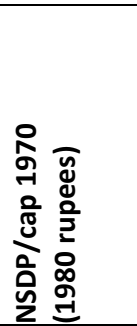 & 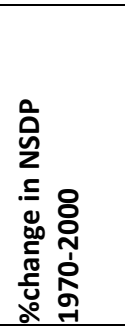 & $\begin{array}{l}\bar{n} \\
8 \\
0 \\
0\end{array}$ & 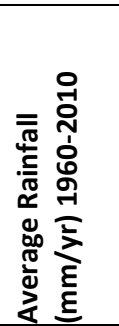 & 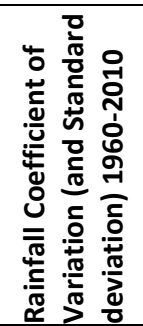 & 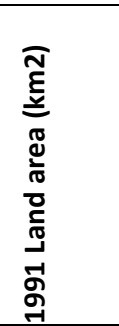 & 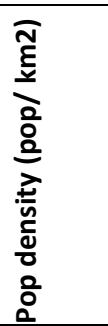 & 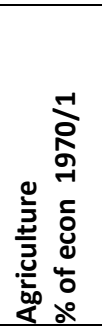 & 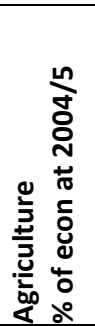 \\
\hline Maharashtra & 493039 & 199122 & $248 \%$ & 96168 & 1134 & $\begin{array}{r}13.8 \% \\
(157 \mathrm{~mm})\end{array}$ & 307713 & 313 & $26 \%$ & $13 \%$ \\
\hline Punjab & 476072 & 211337 & $225 \%$ & 24310 & 606 & $\begin{array}{r}25.7 \% \\
(156 \mathrm{~mm})\end{array}$ & 50362 & 483 & $58 \%$ & $36 \%$ \\
\hline Tamil Nadu & 349795 & 149137 & $345 \%$ & 62183 & 931 & $\begin{array}{r}21.6 \% \\
(201 \mathrm{~mm})\end{array}$ & 130058 & 478 & $39 \%$ & $12 \%$ \\
\hline Karnataka & 347776 & 141830 & $245 \%$ & 52521 & 1168 & $\begin{array}{r}13.6 \% \\
(159 \mathrm{~mm})\end{array}$ & 191791 & 274 & $55 \%$ & $19 \%$ \\
\hline Gujarat & 363138 & 173057 & $210 \%$ & 50172 & 685 & $\begin{array}{r}32.4 \% \\
(222 \mathrm{~mm})\end{array}$ & 196024 & 256 & $43 \%$ & $17 \%$ \\
\hline $\begin{array}{l}\text { Andhra } \\
\text { Pradesh }\end{array}$ & 303193 & 124835 & $243 \%$ & 76045 & 891 & $\begin{array}{r}15.7 \% \\
(140 \mathrm{~mm})\end{array}$ & 275045 & 276 & $54 \%$ & $24 \%$ \\
\hline West Bengal & 337089 & 160787 & $210 \%$ & 79840 & 1914 & $\begin{array}{r}11.8 \% \\
(225 \mathrm{~mm})\end{array}$ & 88752 & 900 & $36 \%$ & $23 \%$ \\
\hline Kerala & 283740 & 144507 & $196 \%$ & 31699 & 2828 & $\begin{array}{r}16.0 \% \\
(452 \mathrm{~mm})\end{array}$ & 38863 & 816 & $43 \%$ & $14 \%$ \\
\hline Haryana & 227194 & 56309 & $403 \%$ & 20919 & 546 & $\begin{array}{r}26.6 \% \\
(145 \mathrm{~mm})\end{array}$ & 44212 & 473 & $64 \%$ & $25 \%$ \\
\hline Rajasthan & 229898 & 148527 & $155 \%$ & 55889 & 441 & $\begin{array}{r}25.4 \% \\
(112 \mathrm{~mm})\end{array}$ & 342239 & 163 & $62 \%$ & $30 \%$ \\
\hline $\begin{array}{l}\text { Madhya } \\
\text { Pradesh }\end{array}$ & 189622 & 174245 & $109 \%$ & 60348 & 1103 & $\begin{array}{r}16.6 \% \\
(183 \mathrm{~mm})\end{array}$ & 443446 & 136 & $56 \%$ & $29 \%$ \\
\hline $\begin{array}{l}\text { Uttar } \\
\text { Pradesh }\end{array}$ & 172448 & 115295 & $150 \%$ & 168289 & 983 & $\begin{array}{r}18.6 \% \\
(183 \mathrm{~mm})\end{array}$ & 294411 & 572 & $59 \%$ & $31 \%$ \\
\hline Orissa & 175312 & 131746 & $133 \%$ & 36623 & 1432 & $\begin{array}{r}15.3 \% \\
(219 \mathrm{~mm})\end{array}$ & 155707 & 235 & $59 \%$ & $24 \%$ \\
\hline Assam & 163315 & 123442 & $132 \%$ & 26368 & 2712 & $\begin{array}{r}17.6 \% \\
(478 \mathrm{~mm})\end{array}$ & 78438 & 336 & $40 \%$ & $29 \%$ \\
\hline Bihar & 104441 & 86828 & $120 \%$ & 81873 & 1216 & $\begin{array}{r}14.6 \% \\
(177 \mathrm{~mm})\end{array}$ & 137877 & 594 & $44 \%$ & $24 \%$ \\
\hline
\end{tabular}

2 Table 1 - Illustration of the range of economic and geographic indicators, listed in

3 descending order of NSDP/Cap (2000), of the 15 Indian states with state populations

4 exceeding 20million. The disparity in NSDP/Capita between the richest state (Maharashtra) 
1 and the poorest state (Bihar) is almost five-fold. This table includes all states extant as of Jan 2000 states with populations of over 20 million people.

4 Rainfall and water resources have been a recurring theme in India's history and development, with its economic management popularly regarded as a 'gamble on the monsoon' (Gadgil, 2003; Wang 2006). This perception persisted throughout the $20^{\text {th }}$ century, despite significant growth of irrigation infrastructure during that period. However, in 2005, a growing argument emerged that the Indian economy was no longer a gamble on the monsoon (Economic Times March 2005, cited in Briscoe and Malik 2006), due to a minimal suppression of growth during low rainfall in 2004-5. Despite an apparently more robust economy during the 2000s, by 2016, the political-economic power of the monsoon was once again clear: “In June 2015, U.S.\$2.3bn was wiped off the Indian stock exchange in less than 48 hours after the government issued a warning about the outlook for this year's monsoon” (C. Lamb, cited in Skroupa, 2016). Such anecdotal evidence suggests that actual or anticipated rainfall shocks still have significant economic impact.

Previous studies have effectively established a significant relationship at a national scale between rainfall variation and GDP growth in India. It has been determined using standard regression tests of growth against deviation of annual rainfall from mean rainfall between 1950 and 2002, that “... about 45\% of the variation in India’s GDP growth is explained by the fluctuation in rainfall” (Virmani, 2006, p.87). Mooley et al. (1981) compared rainfall with crop yields, and found that low rainfall explained $10-50 \%$ of increase in crop prices. Mooley et al.'s method compared the All India Index of Food Prices with year of rainfall identified as having a 'marked deficiency', whereby over $40 \%$ of the country receives rainfall $20 \%$ or more below average. They further found that other variables such as fertiliser, pests and technological improvement represented constant influences on yields, rather than explaining any inter-annual trends. Twenty years later, Cagliarini and Rush (2011) reaffirm the dominant role that rainfall variation plays in the variance of agricultural production in India. They also identify agricultural volatility to fluctuations in the Indian economy as a whole, despite a decline in agricultural contribution to GDP from 30\% in 1980 to $15 \%$ in 2010. In contrast to break points observable in GDP growth rates as a whole, Virmani 2006 finds no break points in agricultural GDP growth, once rainfall has been accounted for, indicating the importance of rainfall in influencing overall growth trends. 
1 While there is a significant relationship between reduced rainfall and reduced growth, Gadgil and Gadgil (2006) note an asymmetry between economic sensitivity to rainfall deficit (drought) and rainfall excess, whereby the costs of a rainfall deficit are of a larger magnitude than the gains in a similar excess year. They also discuss the challenges inherent in using a determinant of rainfall amount to distinguish between 'good' wet years which may enhance crop production and 'economically damaging' wet years where floods may harm crop and other economic assets. In particular, they highlight difficulties in assessing timing and location of rainfall relative to crops and harvest periods (see also Mooley et al., 1981). This difficulty is also highlighted by Gorst (2017) for India, and echoes global trends over uncertainty over rainfall-flood impact noted by Lesk et al (2016). Gadgil and Gadgil (2006) also note the complexity of flood damage due to dam bursts, which may cause damage in a particular location well away from, or well after the time of, a significant high rainfall event.

The historic and complex relationship between rainfall and growth can be seen to have shaped the India's water and economic development throughout modern history. Up to the $19^{\text {th }}$ century, India's agricultural production was predominantly reliant on local water management, with some areas continuing in this manner up to the 1960s (Shah, 2009). During the late $19^{\text {th }}$ and into the $20^{\text {th }}$ century, significant investment in irrigation led to a shift towards centralised and regionalised water management (Briscoe and Malik, 2007). Throughout the $20^{\text {th }}$ century, significant investments were made in irrigation, led by the national government, which had invested a total of Rs920bn up to 1997 (US\$23.7bn based on 1997 rates) (Gulati et al., 2005). In each of India’s 5 year economic plans, irrigation investment represented a prominent destination of funds, commencing at $22 \%$ of total planbased expenditure in the first five year plan (1951-1956), but declining as a proportion of subsequent plans (ibid).

The irrigation investment helped underpin the 'Green Revolution' in Indian agriculture from the 1960s, along with improved crop varieties and other approaches to increase agricultural yields, food security and rural development. The large yield gains of the Green Revolution were also facilitated by subsidies, including fertilisers (supported up to a magnitude of $1 \%$ of national GDP), and state-supported food prices. 
1 million ha (Gulati et al., 2005), although only about 71 million ha is actively utilised (Rao

2 and Hiremath, 2009). India's active irrigated area comprises $40 \%$ of its cultivated agricultural area, but produces 70\% of its crop output (Cagliarini and Rush, 2011). The role of tubewells is significant, with assessments estimating that groundwater now supports $50 \%$ or more of national irrigated area (Briscoe and Malik 2006, Gulati et al. 2006) The rise of tubewell use was enhanced, as part of the 'Green Revolution, by the politically expedient provision of lowcost, unmetered, or area-based electricity, removing energy prices as a barrier to uptake

8 (Gulati and Pahuja 2015, Cagliarini and Rush 2011). With the increase in autonomouslydeveloped groundwater, farmers have also become less dependent on irrigation departments and government agencies for the coordination and financing of new irrigation capacity, leading to uncoordinated irrigation development (Briscoe and Malik, 2006). As well as providing water for crop production, pumping in areas of shallow groundwater lowers the water table, reducing waterlogging and further improving agricultural production. Groundwater-based irrigation has also played a crucial role in increasing yields of previously rainfed areas; between $30 \%$ and $50 \%$ of water requirements in nominally rainfed areas is now provided through groundwater irrigation, building resilience against variability in rainfall (Shah 2009). Today, groundwater plays a crucial role in underpinning food grain production so is regarded as a "powerful engine of the rural economy” (Malik 2016, p.11).

While there are multiple positive aspects to the use of groundwater, much of this water is being abstracted at a rate that exceeds recharge. Briscoe and Malik (2006) estimate that up to $15 \%$ of India's food supply is met through unsustainable groundwater use. The security of the groundwater supply is worsened by the continued provision of free electricity, which encourages over-pumping and irrigation at times when power is available, rather than in volumes and timings required by the crop, and creates grid loads which can lead to blackouts (Malik 2016). Unsustainable groundwater withdrawals in India is significant on a global scale, with Dalin et al. (2017) assessing that $30 \%$ of the of the $292 \mathrm{~km}^{3}$ of annual global groundwater deficit occurs in India, with the global deficit supporting up to $10 \%$ of world food needs. While irrigation would appear to have bolstered food supplies, the dependence on unsustainable groundwater and its weak regulation represents a major challenge for the future of India's agricultural production and allocation of its water resources. The need for action in redressing groundwater dependence was made clear by India's commitment through the Paris Pact on Water and Climate Change Adaptation to improve groundwater management as a means of improve climate resilience (UNFCCC, 2015), and commitment by the Indian 
1 Government at the World Bank to a \$1bn National Groundwater Management Improvement

2 Plan (World Bank, 2017).

4 Over recent decades, Indian agriculture has diversified into higher value products, offering significantly increased returns on inputs (Shah 2009). This includes a shift towards dairy farming instead of rice production. The result has been a declining rate of growth in staple crops, while the population continues to grow. These trends have led Gadgil and Gadgil (2006) to note a potential threat to food security, while conversely, Cagliarini and Rush (2011) highlight opportunities to improve yields and reduce supply chain waste by up to $40 \%$, as a means of maintaining supply with lower national production. At the same time, development pressures and a desire for increased wealth are seen to push farmers into focusing on maximising income opportunities, which, as Briscoe and Malik (2006) note, are most effectively pursued outside agriculture. Agriculture in India is therefore facing a tension between investment in water and agricultural productivity, a desire for lower risks and higher returns, and the continuing potential for losses caused by extreme rainfall events (Garrick and Hall 2014, Dadson et al. 2017, Sadoff et al. 2015).

In addition to diversification within the agricultural sector, diversification of overall state and national economies away from agriculture is often cited as a key means to buffer growth against environmental variability. Grey and Sadoff (2007) for example argue strongly for the need for investment and growth in sectors besides agriculture to enhance overall economic growth and thereby allow for continued investment in water security. The evidence for India however is that economic diversification has not buffered the national economy from hydroclimatic variability. Virmani (2004) explains that economic diversification has resulted in a buffering of hydroclimatic impacts on the supply side of the economy. The supply side of the economy captures the production of goods and services; as the relative economic contribution of agriculture declines, the economy is hypothesised to be less impacted by hydroclimatic variation. However, given the high percentage of the population still engaged in agriculture (Mooley et al., 1981), a reduction in earnings of those dependent on agriculture continues to impact on the purchasing power of a large proportion of that population. This impact is despite the reduced relative contribution of agricultural production (supply) to the economy as a whole. Therefore, Mooley et al. suggest that the decreased impact on the supply side of the economy appears offset by impacts on the demand side. Whilst noting the decline in agricultural importance of GDP, Gadgil and Gadgil (2006) assess that the 
1 economic impact of drought to the Indian economy are relatively constant throughout the 2 period 1951-2003, at between 2-5\% of the GDP, with above average rainfall enhancing GDP on average about $1.2 \%$. They argue that a possible explanation for the dichotomy between declining agricultural importance and continued drought sensitivity is that purchasing power of the agricultural population has become increasingly important in continuing propagation of drought impacts across the economy as a whole.

8 In parallel to these agricultural changes, there have been wider changes within the state and national economies as a whole, and uncertainty over the impact of these changes on growth rates. The literature debates whether a period of higher growth, based on improved resilience to agricultural shocks on rainfall, commenced after reforms towards economic liberalism in 1991-92 (Briscoe and Malik 2006), or whether a statistically significant break point in 198081 marks a new trend in the economy. This earlier date is associated with the re-election of the (liberal) Congress party and the promotion of a pro-business agenda (Virmani, 2006; Sinha and Tejani 2004; Kohli 2006). Structural adjustment and poverty reduction drives during the 1980s and 1990s add a further compounding factor to growth patterns (Dreze and Sen, 2013). While wider national economic policy has an impact on growth rates, at the aggregate national level its effect has proven challenges to identify, adding a further layer of complexity to the analysis of rainfall impacts on growth.

This section has analysed key characteristics of India's natural and economic environment and changes during recent decades, highlighting debates in the literature over trends and causality. The next section draws together key themes and debates, and lays out the hypotheses related to growth, rainfall and buffering mechanisms investigated in this paper.

\section{Research gaps and hypothesis}

While national-level analyses have been carried out into the relationship between rainfall and economic growth, there has, to-date, been no state-level analysis. Such a finer spatial and political resolution enables further interrogation of trends over time. In particular, while an overall Continuous Correlation, i.e. constantly statistically significant relationship between rainfall and growth, is observed in the literature for India, the opportunity is presented to understand which states exhibit correlation, which do not, and how and when the nature of any relationship changes over time. 
2 Rainfall itself is not necessarily the most effective indicator to understand full economic 3 impact of hydroclimatic variability. Previous studies (Sadoff et al., 2015; Brown and Lall, 4 2006, Brown et al 2013) have argued that runoff represents an important proxy for the water 5 available for economic production, and for damage under flood conditions. However, runoff 6 does not necessarily represent variations in rainfall water for agriculture (which is better 7 represented by a soil moisture metric) or groundwater availability. The relationship between 8 rainfall, and opportunity or loss to the economy is highly heterogenous and complex. For India publicly-available surface water data is limited, and resulting data sets have required a degree of abstraction, including through the use of gridded re-analysis derivations. Furthermore, scientific and political discourse on climate and economic growth in India has tended to be focused on rainfall as the key input variable. Therefore while recognising this complexity, and the need to bound this initial analysis, this study focuses solely on rainfall, given the duration of rainfall data at the same state scale as available economic data and in the interests of minimal data transformation.

The first hypothesis under consideration is therefore as follows:

1) The nature of the correlation between rainfall and economic growth varies across states in India and trends also vary over time.

Expanded irrigation, particularly with groundwater, has led to rapid growth in agricultural outputs and independence of farmers from state bureaucracy. Shah’s (2009) argument of yield gains and resilience to drought due to irrigation investment, suggest that states with higher proportion of irrigated lands should exhibit lower correlation between growth and rainfall. Groundwater would be expected to exhibit greater inter-annual stability than rainfall. Therefore states that are now heavily dependent on groundwater-fed irrigation should, accordingly, be expected to have a lower sensitivity to rainfall variation, even if this buffering is threatened by increasing groundwater overdraft. Wetter states, with consequentially less crop water deficit, might be expected to be less impacted by inter-annual reductions in rainfall, and therefore exhibit lower tendency for economic sensitivity to rainfall variation. This leads to a further three hypotheses related to irrigation and water availability: 
3) State-level increase in irrigated agricultural areas reduces the correlation between rainfall and economic growth; and

4) The greater inter-annual stability of groundwater buffers state economic growth from rainfall.

6 Arguments in the development literature on the correlation between rainfall and growth, particularly drought, imply that growth and development is hindered through water-related shocks (Bosworth et al., 2007, Barrios et al., 2010, Brown and Lall, 2006, Brown et al. 2013). Brown et al (2013) provide modelled evidence for a sample of 180 countries that a 1\% increase in drought-stricken area results in a $2.7 \%$ reduction in per capita GDP. Over the longer term however, the argument for costs caused by droughts (and floods) may neglect rebound effects post-drought, and the increased economic activity associated with recovery from shocks. Evidence for these stimulus effects of climate shocks on growth are presented by Skidmore and Toya (2002). However the argument of increased growth can also be considered an example of Bastait’s (1874) Broken Window Paradox. Bastait postulates that while investment to rectify damage appears to stimulate the economy, if that damage had not occurred, it is likely that the money would have been spent or invested in other ways to further growth and development. Additionally, attention needs to be paid to relative wealth and differences in initial conditions for growth that could also be a factor in impacting economic trajectories. A state-level analysis therefore provides the opportunity to assess whether correlation of growth and rainfall is associated with lower levels of growth compared to non-correlated cases. This leads to the fifth hypothesis:

5) correlation between rainfall and economic growth constrains overall growth rates

24 of states.

The reduction in the relative importance of agriculture to the state economy, i.e. economic diversification away from agriculture and water-dependent sectors, is often cited as a means for economies to buffer themselves from the impact of drought (Carrão et al. 2016, Grey and Sadoff 2007). With a larger proportion of a state or national economy not directly inputdependent on rainfall and water availability through agriculture, the impact of inter-annual changes in rainfall on national (or state) economic growth should be reduced. However the evidence discussed above by Gadgil and Gadgil (2006) is that diversification away from 
1 level, to understand whether the economic role of agriculture has been lower where states exhibit no historic sensitivity to rainfall. This leads to the sixth hypothesis:

6) economic diversification away from agriculture buffers economic growth from

4

\section{Data and methodology}

This section discusses the selection and processing of data used in the analysis, and the regression methodology used to analyse state behaviour and change over time.

\section{Economic Data}

The long term economic data used in our analysis is the EPW (Economic and Political Weekly) Research Foundation (2009) state-level data covering annual total and sectoral economic size and population, derived from official national and state records. There are a number of limitations associated with this data (including comparability over the long term, discussed later) but, importantly, as with many developing economies, subsistence agriculture is, by nature, absent from official economic figures (Dinar et al., 1998). It is likely that the absence of this economic component, covering the poorest and most economically and biophysically vulnerable, will tend to mask the impact of rainfall on state economic productivity.

The EPW Foundation economic data comprises time series for all states going back, in most cases, to 1961. The data is divided into discrete baseline sets, reflecting the revision (or rebaselining) of the economy every 10-15 years to better reflect and capture the makeup of the state economy. Each new baseline captures more of the economy, and is therefore larger in its first year than the previous baselined series. The data presented by the EWP foundation include total Net State Domestic Product (NSDP), Agricultural Net State Domestic Product, and population. The following time series are provided:

1961-1970 (baseline1948-9) 1970-1986 (baseline 1970-71) 1980-1999 (baseline 1980-81) 1993-2006 (baseline 1993-94) 
3 Data from 2007 to 2014 was obtained from the Indian Government Open Data Platform

4 (2015), allowing analysis up to the 2012 limit of rainfall data (discussed below). NSDP data,

5 which accounts for capital depreciation, forms a longer time series than Gross State Domestic

6 Product, where data is only available from 1980.

8 Due to changes in NSDP methodology at each baseline, it is impossible to reconstruct properly a comparable historic time series. Annual growth rates can be derived directly from the data. However, in order to compare growth over the longer term, the discrete time series need combining into a single dataset, referenced to the same year. The methodology of retropolation (backcasting) was used as it preserves the inter-annual intervals in the data, at the expense of ignoring inherent errors contained in the older series, namely measuring less of the actual economy (de Le Fuente, 2003; de La Escousura, 2014). The method involves lifting (or lowering) a complete time series such that it scales with a previous (or subsequent) series. All the time series were rescaled to 1980-81 baseline time series, as this was the longest continuous time series provided in the EPW data. The splicing was carried out in the following manner

$$
\mathrm{Y}_{\mathrm{t}-1, \ldots, \mathrm{n}}=\mathrm{Y}_{\mathrm{t}-1, \ldots, \mathrm{n}} *\left(\mathrm{X}_{\mathrm{t}} / \mathrm{Y}_{\mathrm{t}}\right)
$$

22 Where $\mathrm{X}_{\mathrm{t}}$ and $\mathrm{Y}_{\mathrm{t}}$ are overlapping years from the two series, and $\mathrm{Y}_{\mathrm{t}-1}$ is the rescaled earlier time series. Due to slight differences in the impact of new economic baselines between each state, every state was rescaled individually at each rescaling. Rather than splicing the agricultural series separately, Agricultural NSDP was calculated for the retropolated time series based on the agricultural percentage of total NSDP in the original data. Inter-annual growth rate was then recalculated from the new time series'.

\section{Rainfall data}

While state-wise rainfall data is crucial for comparability with economic data and other aggregate state indicators, it masks considerable internal variation within some individual states, presenting a potential constraint to identifying rainfall-growth relationships. In the particular case of Maharashtra, rainfall varies from over $4000 \mathrm{~mm} / \mathrm{yr}$ at the coast to 40 $\mathrm{mm} / \mathrm{yr}$ in the rain shadow of the Western Ghats (Figure 4). In a case like this, it is possible 
1 that aggregating rainfall and economic behaviours at the state-level does not capture crucial 2 sub-state relationships.

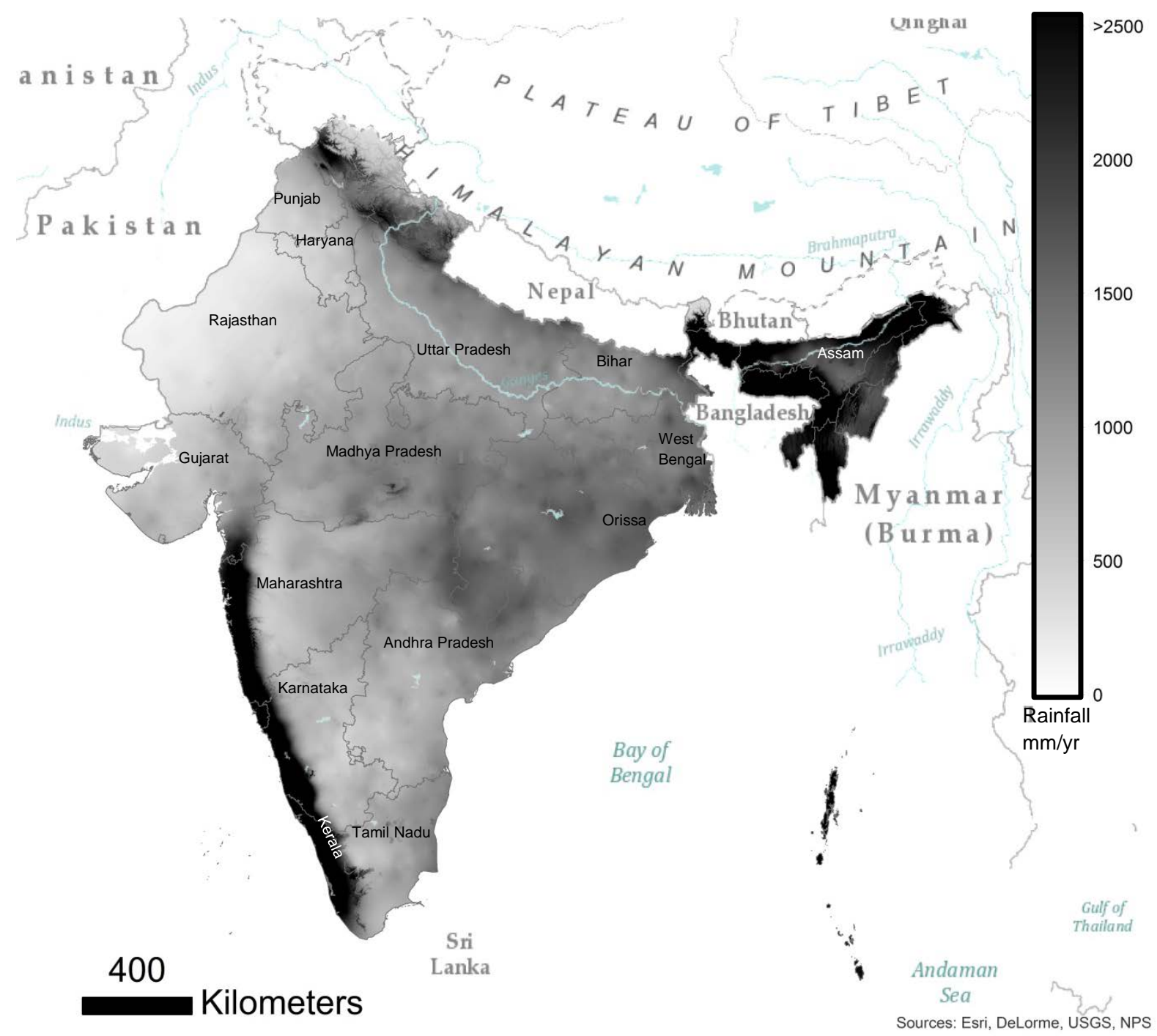

5 Figure 4 - Annual Rainfall (mm/yr) from 1997-2006 over India. Illustrative data from

6 TRMM database, collated by Mulligan (2006), showing 15 states analysed in this study. Map 7 borders and data mask USGS/Esri. NOTE: TRMM derived-data was used in the absence of 8 accessible IMD gridded products. It is noted that global gridded data sets have been assessed 9 to under-represent actual rainfall values especially on the west coast, compared to IMD

10 Gridded data products, although differences are in the order of $+/-50 \mathrm{~mm} / \mathrm{yr}$ elsewhere

11 (Rajeevan et al. 2006), and spatial distribution of gridded global data is regarded as 12 acceptable (Rajeevan et al. 2005).

14 The data chosen for the analysis is the Indian Meteorological Department (IMD)'s monthly 15 subdivisional rainfall series dating back to 1951, aggregated by meteorological subdivisions 
1 that generally follow state boundaries. The largest states are split into multiple subdivisions,

2 while the smaller states are combined into a single subdivision. To obtain average rainfall for

3 states comprising multiple subdivisions, state-wise rainfall was calculated based on the area

4 weighting of subdivisions to each state, following the method of Mooley et al. (1981). GIS

5 area intersections were used to determine the relative contribution of each subdivision to state

6 total area.

7

8 The Hydromet subdivisions were computed in ARC-GIS using boundaries from the Global

9 Administrative Areas Database (GAAD)

10 (http://biogeo.ucdavis.edu/data/gadm2/shp/IND_adm.zip available via gadm.org). This

11 included national, state, district and sub-district levels, last updated in 2012, with Hydromet

12 subdivisional boundaries informed by data from the Centre for Ocean-Land-Atmosphere

13 Studies (COLA) (George Mason University). Hydromet subdivisions have been altered as

14 state boundaries have changed, and the IMD data used the more recent subdivisions, with

15 Figure 5 showing the intersections used to compute the rainfall data in this paper. The rainfall

16 for each state was then calculated as a percentage deviation from state long term average

17 (1951-2012). The use of percentage deviations from average allow the relative impact of

18 changes in rainfall to be understood, and provide standardisation of methodology across

19 states with very different average rainfall patterns. 


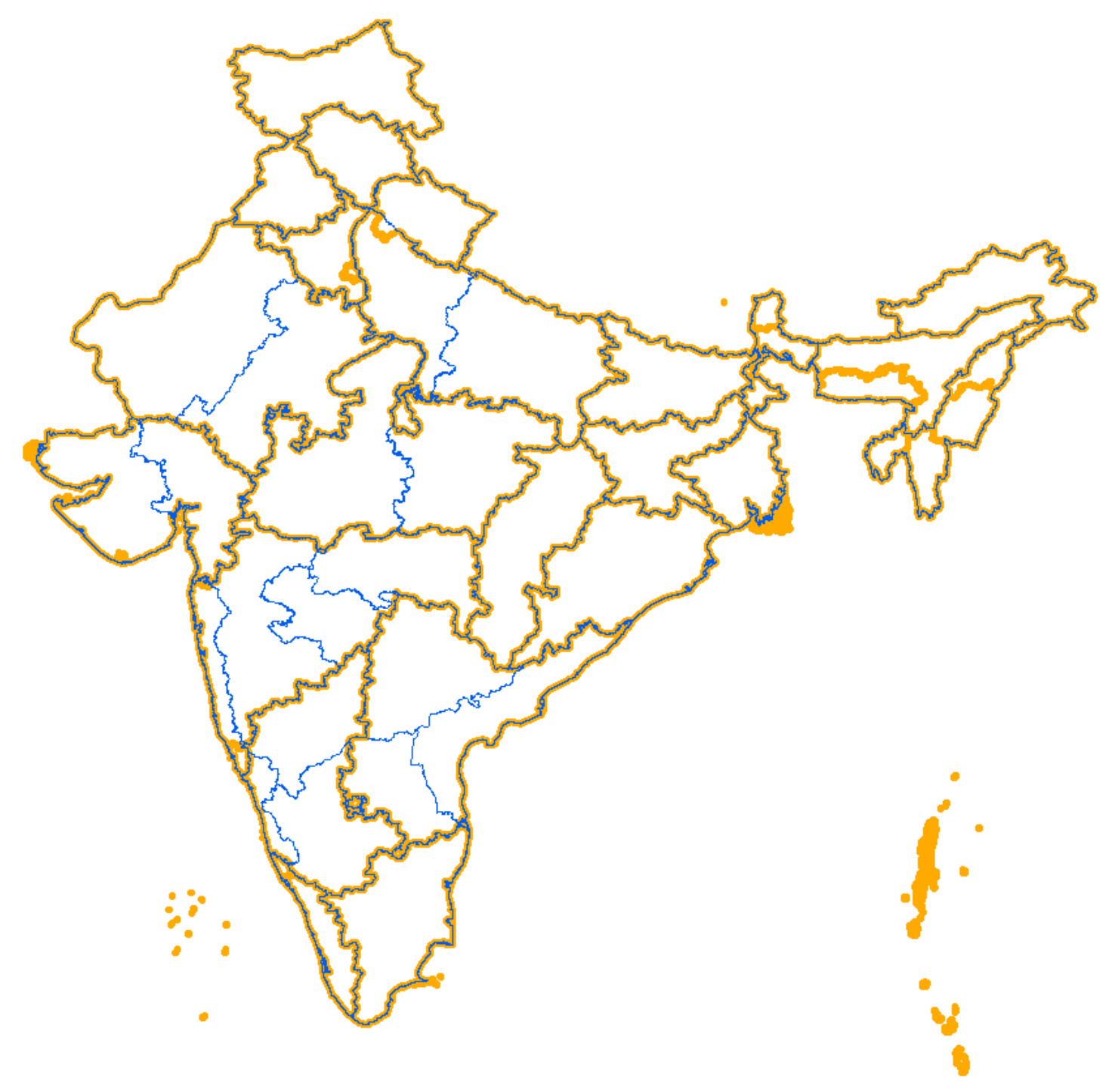

2 Figure 5 - Map showing Indian sates (thick lines) and Hydromet subdivisions (thin lines)

3 (Data: India Meteorological Department).

4

5

6 Additional data

7 The conceptual model of rainfall/growth relationships assumes that growth will be impacted

8 in flood years. However, there is limited long-term systematic data on state-wise flood

9 impact. Attempts to qualitatively identify flood events through media reporting over the past

$10 \quad 10-15$ years for flood-prone Bihar showed no direct correlation between total annual rainfall

11 and any economic signal due to flood losses. The challenge of incorporating flood years into

12 the analysis was further compounded by the cross-border nature of flooding, namely flood

13 damage often being caused by rainfall outside the state, or through infrastructure failure not

14 directly related to large proximate rainfall events (e.g. the embankment breach above Kosi 
1 dam causing the catastrophic 2008 Bihar floods). Additionally, temporal spill-over effects of

2 floods to subsequent years are not captured in the data, meaning that lagged effects on growth

3 cannot be reliability accounted for.

4

5 The Central Water Commission data on flooding (Government of India, 2013) provided a

6 long-term record of flood impacts from 1951 to 2011, with comprehensive annual data

7 covering area impacted, population affected, damage to crops, damage to homes, cattle lost,

8 human lives lost, and financial damage (sum of crops, homes and utilities). Given the

9 incomplete nature of financial damage (including failure to account for business impacts, nor

10 financial quantification of animal losses), two indicators were chosen to represent flood

11 damage: i) 'total damage’ (rescaled to constant 1980 lakh $\left(10^{5}\right)$ rupees), with damage

12 recalculated as a percentage of state NSDP and; ii) the 'population impacted', calculated as a

13 percentage of total state population. This combination of indicators means that indirect

14 monetary losses due to human impact (i.e. reduced purchasing power and market access, as

15 well as an indication of subsistence farming impact) were also incorporated, albeit indirectly.

16 A 'flood year' was then defined as either damage and/or human impact being greater than

17 one standard deviation above the average flood impacts for the state (including years of zero

18 damage). The result was an exclusion of between 1 in 5 and 1 in 10 years from the linear

19 regression analysis subsequently carried out.

21 In addition to flood years, Certain extreme economic data points were excluded. These were

22 removed on the basis of being more than three standard deviations from the mean growth for

23 the entire state time series. Most of the excluded points were in the agricultural time series.

24 Additionally, one year from Bihar was excluded as it included a jump of 43\% of NSDP due

25 to changes in calculation between two spliced time series, the only time when such a large

26 jump was recorded in spliced years. Excluded years are shown in Table 2

27

28

29

30 


\begin{tabular}{|c|c|c|}
\hline \multicolumn{2}{|c|}{ Excluded years from Regression } & \multirow[b]{2}{*}{$\begin{array}{l}\text { Statistical } \\
\text { Outliers }\end{array}$} \\
\hline & Flood Years & \\
\hline $\begin{array}{l}\text { Andhra } \\
\text { Pradesh }\end{array}$ & $\begin{array}{l}\text { 1969-70, 1976-77, 1977-78, 1983-84, } \\
1986-87,1989-90,2006-7\end{array}$ & $\begin{array}{l}1988-89(\mathrm{Ag} \\
\text { growth only) }\end{array}$ \\
\hline Assam & $\begin{array}{l}1982-83,1984-85,1986-87,1989-90 \\
1987-88,1988-89,1993-94,1995-96, \\
1998-99,2002-3,2004-5,2007-8\end{array}$ & \\
\hline Bihar & $\begin{array}{l}1971-72,1974-75,1975-76,1976-77 \\
1978-79,1987-88,2002-3,2004-5\end{array}$ & $\begin{array}{l}\text { 1970-71 (Ag } \\
\text { Only - Splicing } \\
\text { jump) }\end{array}$ \\
\hline Gujarat & $\begin{array}{l}\text { 1970-71, 1973-74, 1975-76, 1975-76, } \\
\text { 1976-77, 1979-80, 1982-83, 1983-84, } \\
1996-97\end{array}$ & \\
\hline Haryana & $\begin{array}{l}\text { 1967-68, 1968-69, 1976-77, 1977-78, } \\
\text { 1978-79, 1983-84, 1988-89, }\end{array}$ & \\
\hline Karnataka & $\begin{array}{l}\text { 1964-65, 1971-72, 1978-89, 1981-82, } \\
\text { 1982-83, 1986-87, 1987-88, 1988-89, } \\
\text { 1989-90, 1990-91, 1991-92, 1993-94, }\end{array}$ & \\
\hline Kerala & $\begin{array}{l}1985-6,1986-87,1989-90,1991-92, \\
1992-93,1997-98\end{array}$ & \\
\hline $\begin{array}{l}\text { Madhya } \\
\text { Pradesh }\end{array}$ & $\begin{array}{l}\text { 1969-70, 1973-74, 1978-79, 1982-83, } \\
\text { 1994-95, 2006-7 }\end{array}$ & $\begin{array}{l}1967-68 \text { (Ag } \\
\text { growth only) }\end{array}$ \\
\hline Maharashtra & $\begin{array}{l}\text { 1970-71, 1983-84- 1984-85, 1989-90, } \\
\text { 1994-95, }\end{array}$ & $\begin{array}{l}\text { 1973-74 (Ag } \\
\text { growth only) }\end{array}$ \\
\hline Orissa & $\begin{array}{l}\text { 1972-73, 1974-75, 1982-83, 1985-86, } \\
\text { 1986-87, 1990-91, 1991-92, }\end{array}$ & \\
\hline Punjab & 1985-86, 1988-89, 1993-94, 1995-96, & \\
\hline Rajasthan & $\begin{array}{l}\text { 1972-73, 1973-74, 1977-78, 1978-79, } \\
\text { 1979-80, 1981-82, 1994-95, 1995-96, } \\
\text { 1998-99, }\end{array}$ & $\begin{array}{l}\text { 2003-4 (Total } \\
\text { and Ag growth) }\end{array}$ \\
\hline Tamil Nadu & $\begin{array}{l}\text { 1972-73, 1973-74, 1977-78, 1979-80, } \\
1983-84,1984-85,1985-86,1992-93\end{array}$ & \\
\hline Uttar Pradesh & $\begin{array}{l}\text { 1971-72, 1973-74, 1976-77, 1978-79, } \\
\text { 1980-81, 1981-82, 1982-83, 1983-84, } \\
\text { 1985-86, 1988-89, }\end{array}$ & \\
\hline West Bengal & $\begin{array}{l}\text { 1968-69, 1969-70, 1970-71, 1971-72, } \\
\text { 1978-79, 1984-85, 1986-87, 1987-88, } \\
1995-96,1999-00,2000-1\end{array}$ & \\
\hline
\end{tabular}

1 Table 2 - data points excluded from regression calculations due to statistically identified 2 flood years or statistical growth outliers. 
1 Data on irrigated area extent and groundwater contribution was derived from the district-level data in the ICRISAT (2012) database. The analysis used data on net cropped area and net irrigated area to establish how much of a state's cultivated area was under irrigation. This database spans the time period 1966 to 2009, and covers a total of 18 states, including the 15 analysed in this paper. Employment data analysing the percentage of working population engaged in agriculture, was sourced from a document by PRS Legislative Research, (2013).

Analytical Methodology

When presented as a visual plot of rainfall and growth data, a number of states exhibited a clear relationship between the two variables. The case of Gujarat is shown in Figure 7 below with R-squared values for correlation of rainfall with total economic output and agricultural output over the 1961-2012 period of 0.468 and 0.524 respectively.

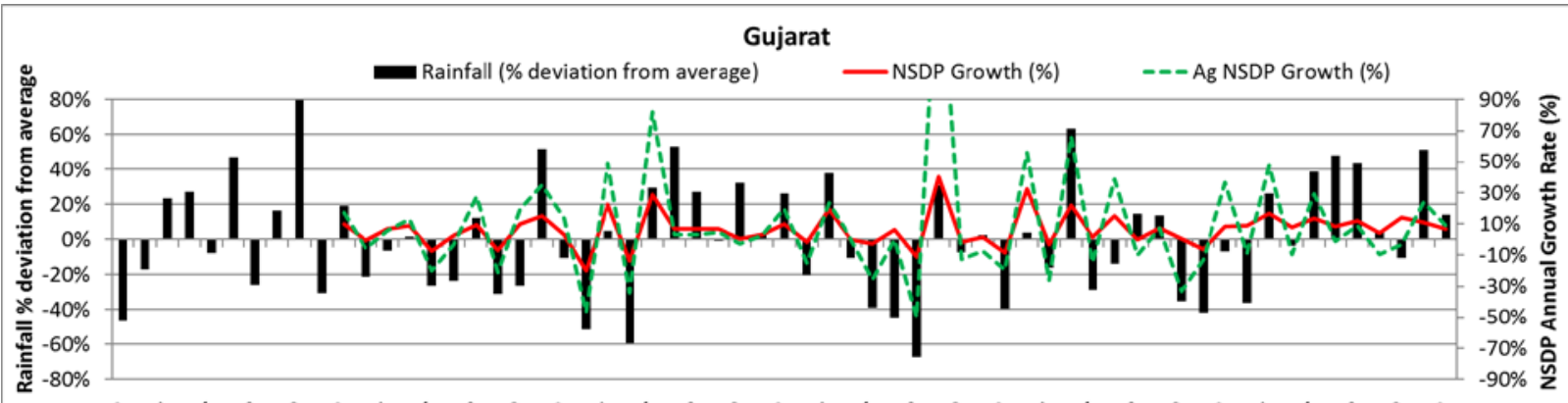

Figure 7 - Plot of rainfall (deviation from mean) and annual NSDP and Agricultural NSDP growth for Gujarat.

The core methodology used in this paper to understand the relationship between annual variations in rainfall and changes in economic growth is a linear regression between the two variables, using a simple bivariate analysis between annual rainfall deviation from the mean and economic growth. A first analytical step was to run linear regression calculations on the entire available time series. This identified some potentially significant relationships between rainfall and growth, and other cases with no apparent or not statistically significant relationships. In order to test the strength of the relationships over time, and assess any 
1 changes in the nature of the relationship, a 25 year trailing moving window linear regression

2 analysis was subsequently carried out. This showed the extent of stability of the regression

3 relationship throughout the available time data. In the cases where the regression transitioned

4 from significant ( $>0.95)$ to non-significant, change points were identified by the time when

5 the correlation ceases to be significant and this change is sustained throughout the remaining

6 data. The following section examines the results of these regressions, the behaviour

7 identified, and the investigation of the other hypotheses presented earlier in this paper.

8

9

\section{Results and Analysis}

\subsection{Correlation behaviour}

Hypothesis 1 appears to be supported by the evidence, that there are different statistically significant behaviour evident for rainfall-growth relationships across Indian states, including instances where the relationship changes over time.

The following three types of relationships were identified for the 15 states analysed, based on the trends in statistical significance of rainfall-growth relationships over time:

- Continuously Correlated - a generally statistically significant relationship between rainfall and economic growth from 1961 to 2012, without sustained departure from statistical significance.

- Never Correlated - no statistically significant relationship between rainfall and economic growth observed from 1961-2012.

- Decayed Correlation - a transition from a statistically significant correlation to a nonsignificant relationship.

\section{Continuously Correlated.}

Six states exhibit statistically significant Continuous Correlated relationship throughout the available data period (Figure 8). The relationship is constantly significant for Andhra Pradesh, Gujarat, Madhya Pradesh, Rajasthan, and Tamil Nadu. All have large dry or desert areas. The sixth Continuously Correlated state, Orissa, experiences some periods where the relationship is not significant at $95 \%$, but this is transitory, and agriculture remains 
1 significantly correlated throughout. Interestingly, Andhra Pradesh exhibits periods of decayed correlation of agricultural growth, while NSDP as a whole remains correlated. This appears counter-intuitive, given that, as argued in the literature, agriculture is the primary driver of transition of rainfall variation through the economy.

\section{Never Correlated}

7 Five states, Assam, Kerala, Maharashtra, Punjab and West Bengal, are denoted Never

8 Correlated, given that there is no statistical relationship between rainfall variation and economic growth observed with available data. Neither total nor agricultural NSDP have robust sensitivity to inter-annual rainfall variation. These five states all are geographically heterogeneous, comprising highland and coastal areas, and diverse in terms of size and wealth, but most (except Punjab) have relatively high and reliable rainfall. There are 3 years towards the early part of the time series where some significance is shown for Maharashtra, but this is not deemed sufficient to establish correlated behaviour.

\section{Decayed Correlation}

Bihar, Haryana, Karnataka and Uttar Pradesh all exhibit Decayed Correlation, from a statistically significant correlation to a non-significant relationship (Figure 9). There is diversity in the environmental and economic circumstance of these states, which could indicate a multiplicity of factors influencing observed trends. Bihar and Uttar Pradesh are large, poor floodplain states, with low-value irrigation and frequent flooding. Haryana by contrast is dry, but receives significant economic spill-overs from Delhi. Karnataka is geographically diverse, with a dry interior, but a rapidly modernising economy.

Bihar and Haryana's NSDP correlation decays to insignificance quite cleanly in the mid1990s. This would appear to coincide with the timing of the economic liberalisation noted in the early 1990s. The statistical changes do not appear to be influenced by the break point of the early 1980s discussed in the literature above. For Bihar, agricultural correlation is not significant at $95 \%$ for the first part of the data series, before obtaining significance, and then losing it just slightly prior to the total economy correlation decay. A partial explanation for this behaviour may be due to discontinuities in the data; Bihar is one of two states (along with Assam) for which there is notable discontinuity in Agricultural NSDP between baseline series, with a jump of 42\% from 1969 to 1970, associated with the new measurement methodology of economic growth. It is further noted that monitoring and reporting for Bihar 
1 may be impacted by its history of political turbulence and administrative challenges, see for example Rai and Pendey, 1981.

4 Haryana sees the correlation of the agriculture sector decays about four years before the economy as a whole. As with Bihar, these behaviours appears counterintuitive; a potential mechanism to explain this behaviour might be the idea that investment in reducing agricultural risk, thereby increasing the role of water as a factor of production, can impact the economy as a whole.

By contrast, for Uttar Pradesh, the sensitivity of the total economy exhibits Decayed Correlation before the agricultural economy; the agricultural trend as of 2010 is still significantly correlated. Karnataka represents a less stable trend, with a small number of correlated years observed in an otherwise decayed correlation series, although too few for statistically robust insights on behaviour. The agricultural economy resumes correlation in 2002, and remains significantly impacted by rainfall. The case of Karnataka demonstrates that a decay of correlation between rainfall and growth is not necessarily an irreversible process. It also shows however that, as with Uttar Pradesh, the economy as a whole can exhibit decayed correlation while agriculture remains sensitive to rainfall variation. There therefore appear to be a number of different permutations of sequencing and likely causality behind a decayed correlation.

Importantly, the indicative break points for the states do not coincide with any of the NSDP time series re-baseline years. Therefore, it is unlikely that re-baselining and accompanying new economic measurement methodologies has influenced the emergence of decayed correlation trends. For Bihar and Haryana, the statistical significance of the correlated relationship of NSDP decays in the late 1990s, well after the 1993/4 re-baselining. For Karnataka, the first instance of decayed correlation is towards the end of the 1980 baseline series (in 1990), while Uttar Pradesh’s decayed correlation is in the middle of the 1999-2007 baseline series.

Bihar is the poorest of the states analysed. With agriculture leading the apparent decayed sensitivity, it is postulated that increases in agricultural growth from a very low baseline are driving increases in income at a scale much greater than previous variations due to rainfall. 
1 of 2004/5, some of the highest rates of state poverty, at 54\% and 41\% (Open Government

2 Data Platform 2013b) respectively. It is therefore possible these states are in a low-level

3 equilibrium trap (Dadson et al., 2017), with rainfall-related losses continuing despite, or

4 indeed because of infrastructure and other investments in water security; water related

5 investments may act to increase the assets at risk of loss or damage in extreme rainfall years.

6 The mechanisms and possible causalities being the correlation between rainfall and growth

7 must therefore be viewed in the specific contexts of the states.

8

9 The potential for a low-level equilibrium trap may be especially pertinent for Bihar, which is the only state to exhibit a nascent inverse-correlation between rainfall and growth, suggesting exposure and losses of a growing asset base to high rainfall events. It is therefore the only state to fully conform with the conceptual model in Figure 3. As Figure 10 illustrates, regression of the five identified flood year results weaken inverse correlation, on the cusp of statistical significance with a p value of 0.054. The two largest flood years of 1971-2 with $32 \%$ and 1987/88 with 25\% above average rainfall, are associated with low or negative growth. While Bihar was the only state to statistically indicate economic sensitivity to flooding, it also illustrates the inherent weaknesses in assessing flood impact, and establishing relationships with rainfall occurrence. The 2008 floods in Bihar do not feature in the sample of excluded years (based on economic and population impact data), despite being reported as one of the worst in Bihar's history. The 2008 floods were caused by an embankment failure on the Kosi tributary to the Ganges, just above the Kosi dam on the India-Nepal border, causing a very large release of water flowing across Bihar to the east of the embanked river. The event was therefore not related to high immediate rainfall nor a physical event within the borders of the state of Bihar. The flood event was therefore disconnected from the annual rainfall signature in Bihar, illustrating the challenges of linking economic flood impacts with state-wise rainfall. Haryana and Rajasthan also have statistically significant regression of flood years with p value of 0.017 and 0.029 respectively, however unlike Bihar, these are not inversely correlated, and do not therefore adhere to the conceptual model in Figure 3. 


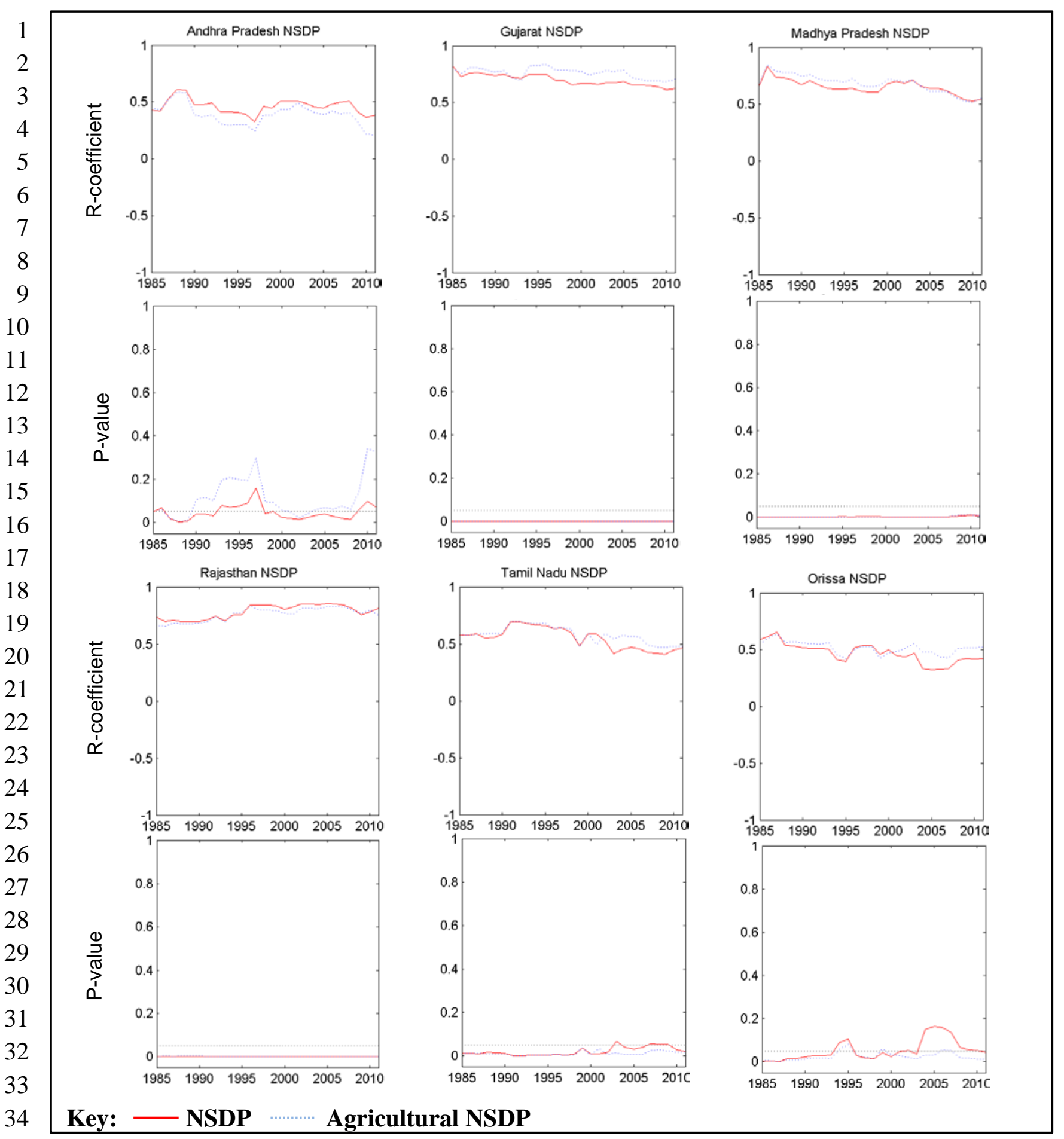

35 Figure 8 - Continuously Correlated states, as demonstrated by regression coefficient and p-

36 value for 25 year trailing moving window ( $\mathrm{x}$-axis marks the end year of the window) of

37 rainfall variation against economic growth. 95\% confidence intervals are shown (straight

38 dotted line) in the P-value graphs. Solid line is total NSDP, dotted line is agricultural NSDP. 

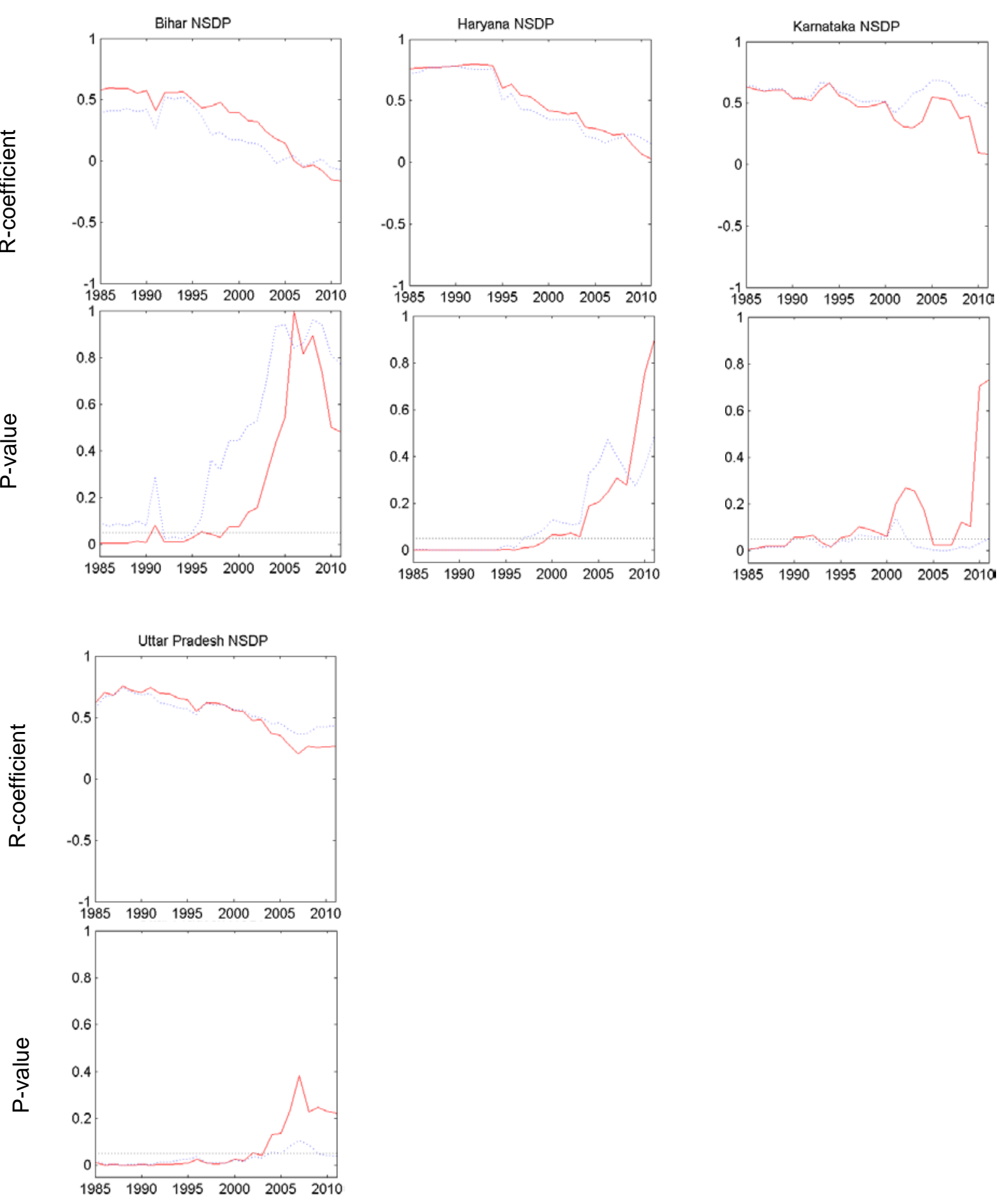

40 Figure 9 - Decayed Correlation states, as demonstrated by regression coefficient for 25 year

41 trailing moving window ( $\mathrm{x}$-axis marks the end year of the window) of rainfall variation

42 against economic growth. 95\% confidence intervals are shown in the P-value graphs. 


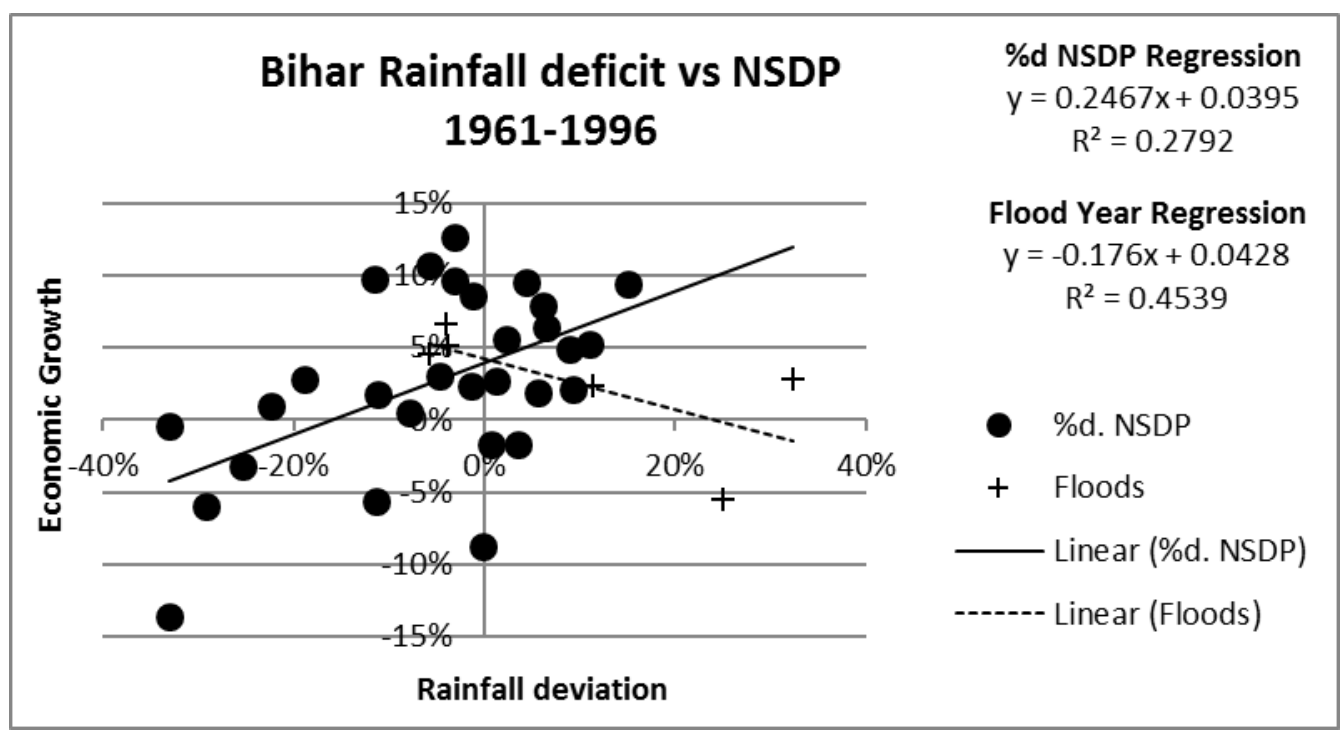

3 Figure 10 - Linear plot of rainfall and economic growth for Bihar, 1961-1996, with flood 4 years plotted separately.

5

6 To summarise the observed relationships, total regression statistics are shown for

7 continuously correlated states (single regression calculation for 1960-2012), the correlated

8 period of decayed correlation states (single regression calculation ending in decay year) are

9 shown in the Table 3, below. This indicates that the regression coefficient for Agricultural

10 NSDP is generally higher than NSDP, indicating a greater sensitivity to percentage deviation

11 in rainfall from the average. Note due to a single statistic covering the entire correlated

12 period, statistical strength of these relationships is weaker than the moving window analysis 13 above.

14

15

16

17

18

19

20

21

22 


\begin{tabular}{|l|r|r|l|r|r|l|}
\hline & \multicolumn{1}{|l|}{$\begin{array}{l}\text { NDSP } \\
\text { Coefficient }\end{array}$} & $\begin{array}{l}\text { NDSP } \\
\text { Rquared }\end{array}$ & Timeframe & \multicolumn{1}{l|}{$\begin{array}{l}\text { Ag NDSP } \\
\text { Coefficient }\end{array}$} & $\begin{array}{l}\text { R- } \\
\text { RqSP } \\
\text { squared }\end{array}$ & Timeframe \\
\hline Andhra & 0.18 & 0.24 & $1961-2012$ & 0.29 & 0.15 & $1961-2012$ \\
\hline Pradesh & 0.24 & 0.47 & $1961-2012$ & 0.58 & 0.52 & $1961-2012$ \\
\hline Majarat & 0.41 & 0.40 & $1961-2012$ & 0.74 & 0.46 & $1961-2012$ \\
\hline Pradesh & 0.29 & 0.54 & $1961-2012$ & 0.51 & 0.51 & $1961-2012$ \\
\hline Rajasthan & 0.11 & 0.20 & $1961-2012$ & 0.27 & 0.26 & $1961-2012$ \\
\hline Orissa/Odisha & 0.27 & 0.22 & $1961-2012$ & 0.48 & 0.24 & $1961-2012$ \\
\hline Bihar & 0.26 & 0.35 & $1961-1996$ & 0.53 & 0.34 & $1961-1995$ \\
\hline Haryana & 0.12 & 0.26 & $1967-1999$ & 0.24 & 0.31 & $1967-1999$ \\
\hline Karnataka & 0.19 & 0.35 & $1961-1995$ & 0.33 & 0.35 & $1961-1996$ \\
\hline Uttar Pradesh & 0.15 & 0.23 & $1962-2003$ & 0.29 & 0.31 & $1962-2003$ \\
\hline Assam & -0.05 & 0.09 & $1971-2012$ & 0.01 & 0.00 & $1971-2012$ \\
\hline Kerala & 0.03 & 0.02 & $1961-2012$ & 0.04 & 0.01 & $1961-2012$ \\
\hline Maharashtra & 0.11 & 0.1 & $1961-2012$ & 0.24 & 0.07 & $1961-2012$ \\
\hline Punjab & 0.00 & 0.00 & $1961-2012$ & 0.02 & 0.00 & $1961-2012$ \\
\hline West Bengal & 0.01 & 0.1 & $1961-2012$ & 0.05 & 0.00 & $1961-2012$ \\
\hline
\end{tabular}

1 Table 3 - Table of regression statics for periods of correlation between growth and rainfall

2 for Continuously Correlate and Decayed Correlation States.

54.2 Factors that may influence correlation behaviours

6 A number of indicators were further assessed against the three categories of state behaviour,

7 to identify any underlying causes and impacts of the Correlated and Decayed Correlation

8 trends.

10 Rainfall

11 Absolute rainfall volume tends to influence the extent of economic correlation to rainfall

12 variation: drier states tend to be correlated, wetter states tend never to be correlated, and the

13 decayed correlation states occupy middle range (Figure 11). The three wettest states of West

14 Bengal, Assam and Kerala have never experienced any correlation. This trend reinforces

15 arguments in the literature that absolute water availability has a fundamental impact on 
1 economic resilience (Sadoff et al., 2015). There is however a considerable range to the 2 observed rainfall in each category, and overlap between all the categories. While rainfall is 3 therefore likely to be influencing correlation, it is not robustly so, and there are other factors 4 influencing economic sensitivity to rainfall. There is no statistical difference between the 5 Decayed Correlation states and either of the other two categories. Only when Punjab is 6 removed from the Never Correlated Sample (as an atypically dryer state dependent on water 7 inflows from neighbours) is there a significant difference compared to the remaining 10 states 8 in a one-tailed t-test $(\mathrm{p}=0.048)$. Hypothesis 2 is therefore statistically rejected, but would appear to be likely influential on the basis of qualitative assessment of wider circumstances in explaining why some states are Never Correlated. Rainfall does not contribute an explanation as to why the four Decayed Correlation states behave as they do.

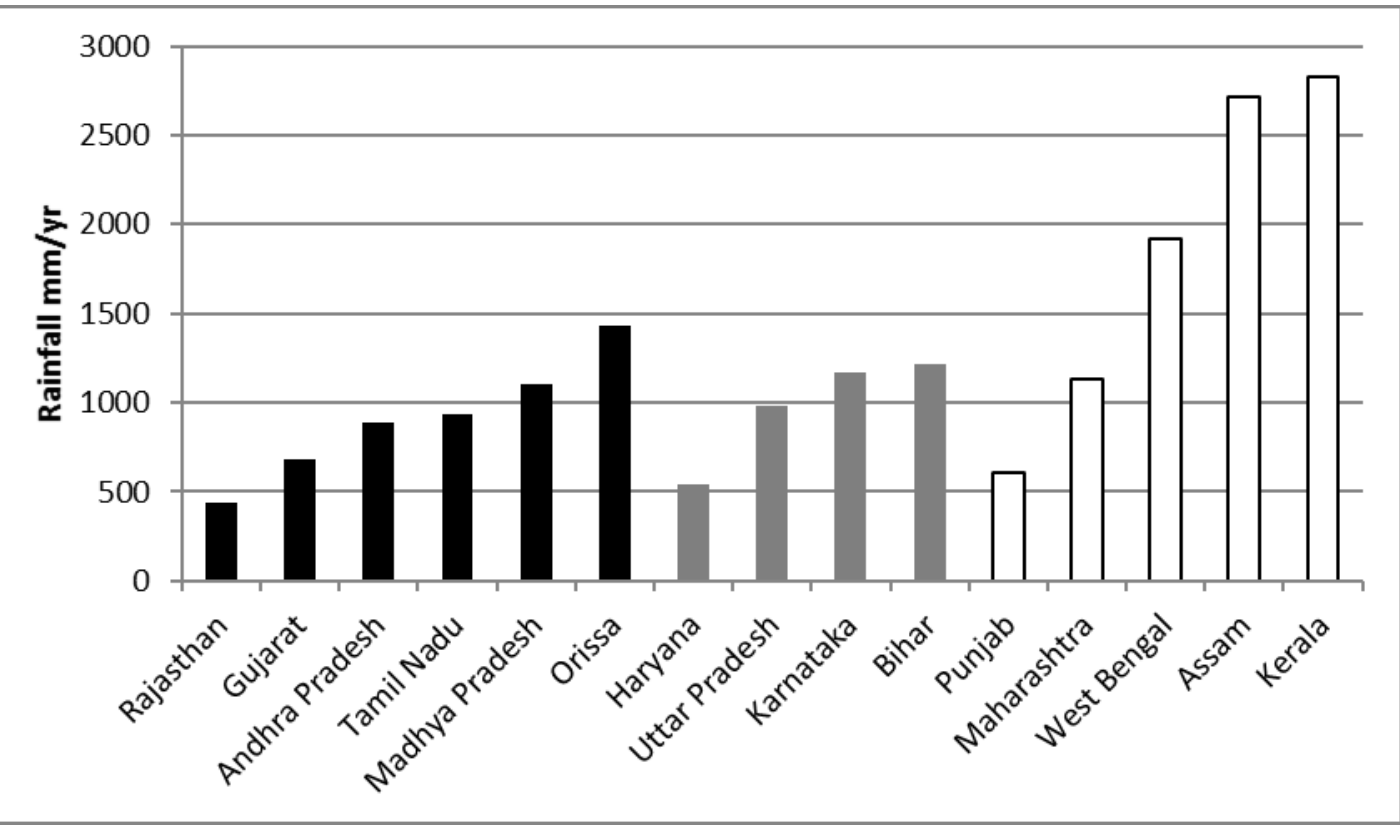

14 Figure 11 - Average rainfall per state, grouped according to Continuously Correlated 15 (black), Decayed Correlation (grey) and Never Correlated (white).

\section{Irrigation area}

18 Table 4 shows the changes in average irrigated area between 1970 and 2000. The evidence shows clearly that Continuous Correlation states have the lowest percentage of irrigated area in both 1970 and 2000. Importantly, by 2000, the Decayed (or soon to decay) Correlation states have the largest irrigated areas, and have also experienced both the largest net and 22 relative changes in irrigated area between 1970 and 2000. In particular, Decayed Correlation 23 states, taken as a group, have doubled their irrigated area relative to area under cultivation, 
1 but also have the largest percentage irrigation areas both in 1970s and 2000. The percentage

2 irrigation expansion of decayed correlation states, as compared to all other states, is

3 statistically different (one-tail t-test, $\mathrm{P}=0.04$ )

4

5 When examined individually, aside from Karnataka, the remaining three Decayed Correlation

6 states show a uniquely large expansion in irrigated area (Figure 12). Karnataka itself doubled

7 its irrigated area from $13 \%$ to $25 \%$ between 1970 and 2000, although all states with less than

8 15\% irrigated area in 1970s experienced a doubling or greater of their irrigated area (as

9 percentage of cultivated area) by 2000. The data, while limited by a very small sample in

10 each behavioural category, provides evidence that expanded irrigation area is associated with

11 a state's Decayed Correlation of economic growth from variation in rainfall. Hypothesis 3

12 therefore appears to be supported, within the limits of available data, that irrigation expansion

13 is related to Decayed Correlation between rainfall and economic growth.

\begin{tabular}{|l|l|l|l|}
\hline & $\begin{array}{l}\text { Percentage of } \\
\text { cultivated area } \\
\text { under } \\
\text { irrigation in } \\
\mathbf{1 9 7 0}\end{array}$ & $\begin{array}{l}\text { Percentage of } \\
\text { cultivated area } \\
\text { under } \\
\text { irrigation in } \\
\mathbf{2 0 0 0}\end{array}$ & $\begin{array}{l}\text { Net } \\
\text { Change }\end{array}$ \\
\hline $\begin{array}{l}\text { Continuously } \\
\text { Correlated }\end{array}$ & $20.4 \%$ & $35.4 \%$ & $14.8 \%$ \\
\hline $\begin{array}{l}\text { Decayed } \\
\text { Correlation }\end{array}$ & $30.7 \%$ & $60.7 \%$ & $30.0 \%$ \\
\hline $\begin{array}{l}\text { Never } \\
\text { Correlated }\end{array}$ & $28.9 \%$ & $41.4 \%$ & $12.2 \%$ \\
\hline
\end{tabular}

16 Table 4 - relative irrigated areas and expansion between 1970 and 2000 by different state

17 behaviours 


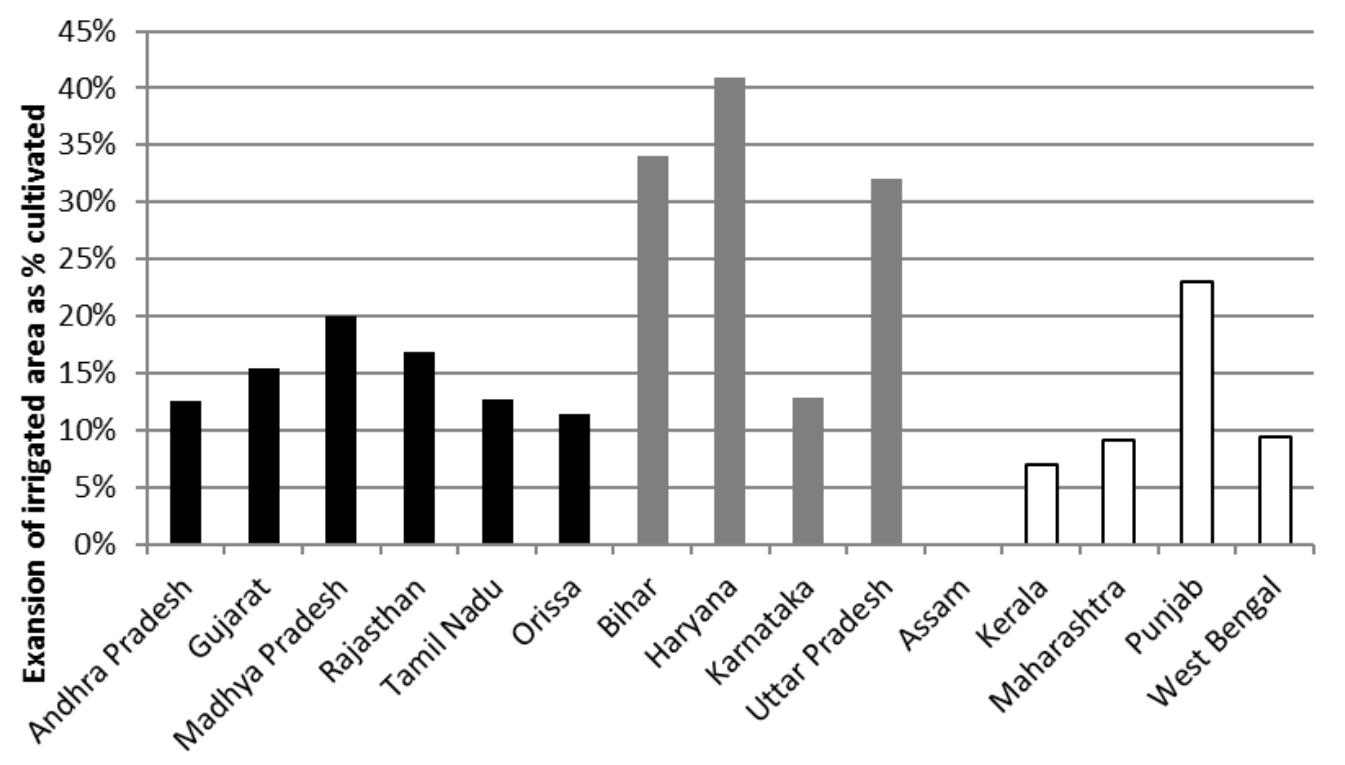

2 Figure 12 - Expansion of irrigated area (as net percent of cultivated area) between 1970 and

32000 (note: there is no ICRISAT irrigation area data available for Assam), grouped according to Continuously Correlated (black), Decayed Correlation (grey) and Never Correlated (white)

6 Groundwater

7 Table 5 shows the growing importance of groundwater to irrigation between 1970 and 2000 .

8 Hypothesis 4 asserted that groundwater, with its inherent inter-annual buffering, should act to 9 reduce the impact of variation in rainfall on growth. The evidence does not support this.

10 Continuously Correlated states have the highest dependence on groundwater in both 1970 and

11 2000, with Never Correlated the lowest. The hypothesis relies on groundwater being a

12 temporally more reliable supply. However data on aggregate groundwater contribution to

13 irrigation does not discriminate between deep wells providing long-term storage, or shallow groundwater that includes annual recharge or seepage from canals and is therefore a resource that will be influenced by annual precipitation. The lack of further data on relative importance of deep or shallow wells means that it has not been possible to disaggregate those states where groundwater irrigation growth is supported by rainfall-sensitive resources. It is also expected that there is a degree of autocorrelation between states where surface water is less abundant (i.e. a tendency to be more vulnerable to variations in rainfall) and where groundwater is more heavily developed; it would be likely that states with more abundant rainfall will be less dependent on groundwater. Groundwater expansion may therefore be reducing the impact of limited surface water, but not providing a means to prevent correlation. Figure 13 provides a breakdown of relative contribution of groundwater to 
1 irrigated area by state, demonstrating that the wettest states (West Bengal and Kerala) have

2 the lowest reliance on groundwater. Note also that the trends for Never Correlated states are

3 very diverse, encompassing both the lowest and some of the highest groundwater

4 dependences.

5

6 Further investigation of any groundwater impact would require a thorough analysis of data on

7 groundwater depths, and seasonal drawdown, as well as geological information about aquifer

8 properties to assess the temporal resilience of different groundwater contributions. The

9 hypothesis that groundwater use buffers the economy from sensitivity to rainfall does not appear to be supported by the analysis. As noted above however, the groundwater revolution allowed independent, unregulated development of irrigated lands. Therefore, it is possible that any enhanced supply reliability is countered by over-development of agriculture and water resources. It is also possible that the assessment of groundwater-dependent agricultural areas are under-estimating true irrigation dependence; in states where charges are based on areas, farmers may be incentivised to under-report surface irrigation to reduce charging liabilities. There are no statistically significant differences between groundwater contribution or expansion of the three different behaviours, and Hypothesis 4 is therefore not proven, and groundwater cannot be considered a buffer to the influence of rainfall on growth.

\begin{tabular}{|l|l|l|}
\hline & $\begin{array}{l}\text { Groundwater } \\
\text { \% contribution } \\
\text { to irrigated } \\
\text { area in } \mathbf{1 9 7 0}\end{array}$ & $\begin{array}{l}\text { Groundwater \% } \\
\text { contribution to } \\
\text { irrigated area in } \\
\mathbf{2 0 0 0}\end{array}$ \\
\hline Continuously Correlated & $38.0 \%$ & $59.5 \%$ \\
\hline Decayed Correlation & $35.3 \%$ & $56.3 \%$ \\
\hline Never Correlated & $30.4 \%$ & $41.4 \%$ \\
\hline
\end{tabular}

Table 5 - Groundwater contribution to irrigation 


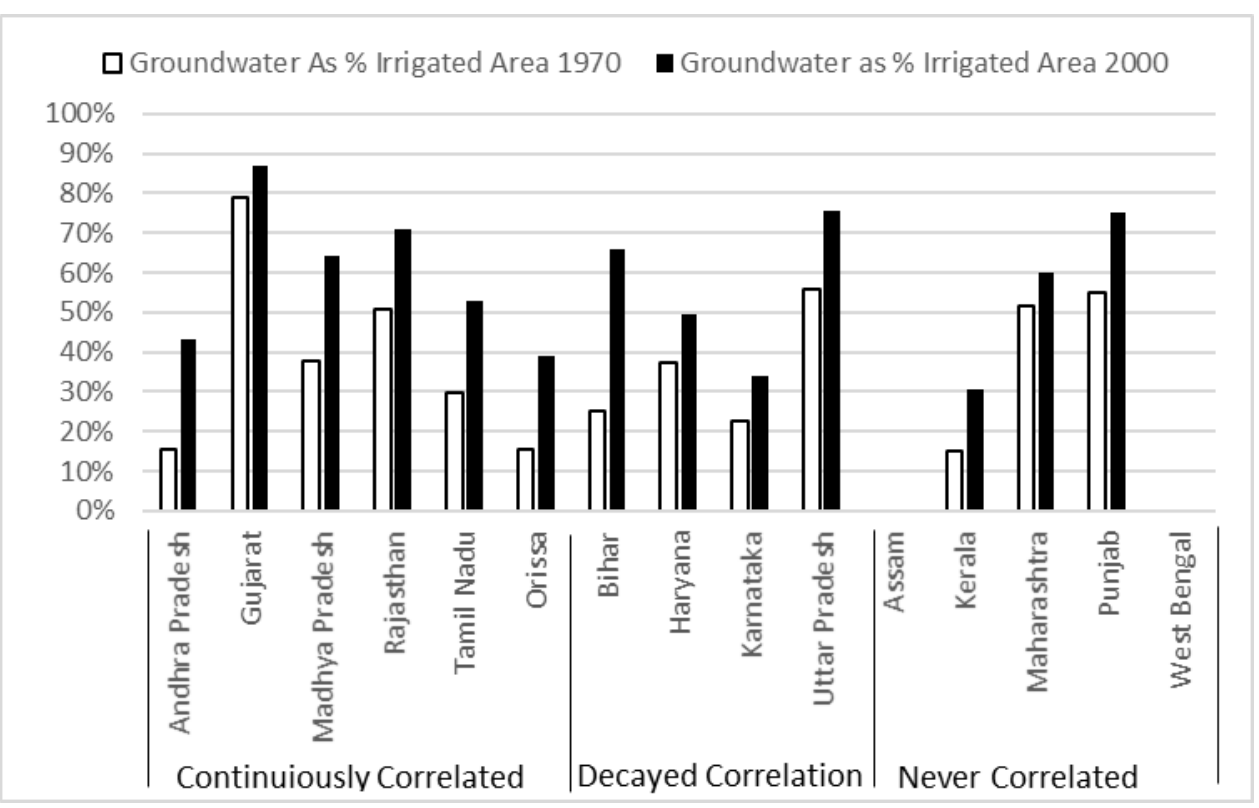

2 Figure 13 - Groundwater contribution to irrigated area (\%) 1970 and 2000.

$4 \quad 4.3$ Factors that may be influenced by correlation behaviours

5 Growth Rates

6 There is a large range of growth rates of the states sampled. The variance of growth rates in each behavioural category is such that differences between the categories are not statistically significant. There are however some indicative trends that are worthy of discussion, along with the compounding factors that pose challenges to understanding long-term economic impact. As a group, Continuously Correlated states grew at an average of 4.8\% between 1961 and 2007, Decayed Correlation states grew at 4.7\%, and Never Correlated states at $4.4 \%$ (Figure 14). As of 2000, GDP/capita was highest in Never Correlated states, at 351 thousand rupees, lowest in Decayed Correlation states, at 210 thousand rupees, and 268 thousand rupees in Continuously Correlated states; this sequence was also apparent in 1970.

The interaction between growth rates and per-capita income appears qualitatively interesting. Figure 15 suggest that the Never Correlated states have higher per capita NSDP relative to their average growth rates than other states. These trends indicate that while Continuously or Decayed Correlation states are growing faster on average than Never Correlated states, they are doing so from a much lower per capita income base.

None of the categorisation of correlation differs statistically significantly in terms of growth rates or per capita income from the remaining sample, indicating that rebound effects in good 
1 years are countering the impact of low rainfall in states which are, or have been, correlated.

2 However the tendency for higher per capita incomes in Never Correlated States does suggest

3 potential for a low-level equilibrium trap as postulated by Grey and Sadoff (2007) and further developed by Dadson et al. (2017). State economies currently or previously correlated with rainfall do appear to have lower per capita income, and while they are growing on average faster than Never Correlated states, are starting from a much lower income base.

8 A further complication of the growth story is the lack of clear relationship between state income and the extent of agricultural and irrigation investment. Indian irrigation is supported by significant international financial flows, as well as the internal redistribution of funds across the country through national government investments in the five year planning cycles. Therefore, there may be an additional degree of buffering of growth impacts through the operation of the wider political structure of India, not accounted for in the conceptual model of Dadson et al. (2017). This arguably clouds the full picture of rainfall-related economic losses.

Additionally, while the states have been analysed in this paper as distinct economic units, considerable interdependence exists between them. The role of trade and flows of products (including agricultural productions) between states, including in drought years to counter reduced domestic food production, will have an unknown impact on state economy as no record of such flows are kept by the authorities (Malik 2016, pers. comm.). Cross-state trade can both mitigate the impact of reduced rainfall in a drought-state, and propagate drought or flood impacts to neighbouring states through reduced availability of products or infrastructure. Potential multi-variate regression, accounting for rainfall and growth in neighbouring states might provide an avenue to understand economic interdependencies between states, and potential transfer or mitigation of impacts between states, building on the single-state analysis explored in this paper. The picture presented by growth rates is therefore complex with those currently and previously correlated states actually growing the fastest, but from the lowest per capita starting points. Hypothesis 5 that sensitivity of the economy to rainfall acts as a constraint on growth is not statistically proven.

It is noted however that the analysis only captures a 42-year window from 1970 to 2012, representing a particular moment in the development history of each state. Given the possible diversity of causalities behind the decayed correlation, it is postulated that some of the 
1 instances of correlation decay, particularly in Bihar, may reverse as income increases and 2 assets become more susceptible to loss. Further research will be necessary as additional data 3 becomes available to understand whether a decay in correlation is permanent or transient. 4

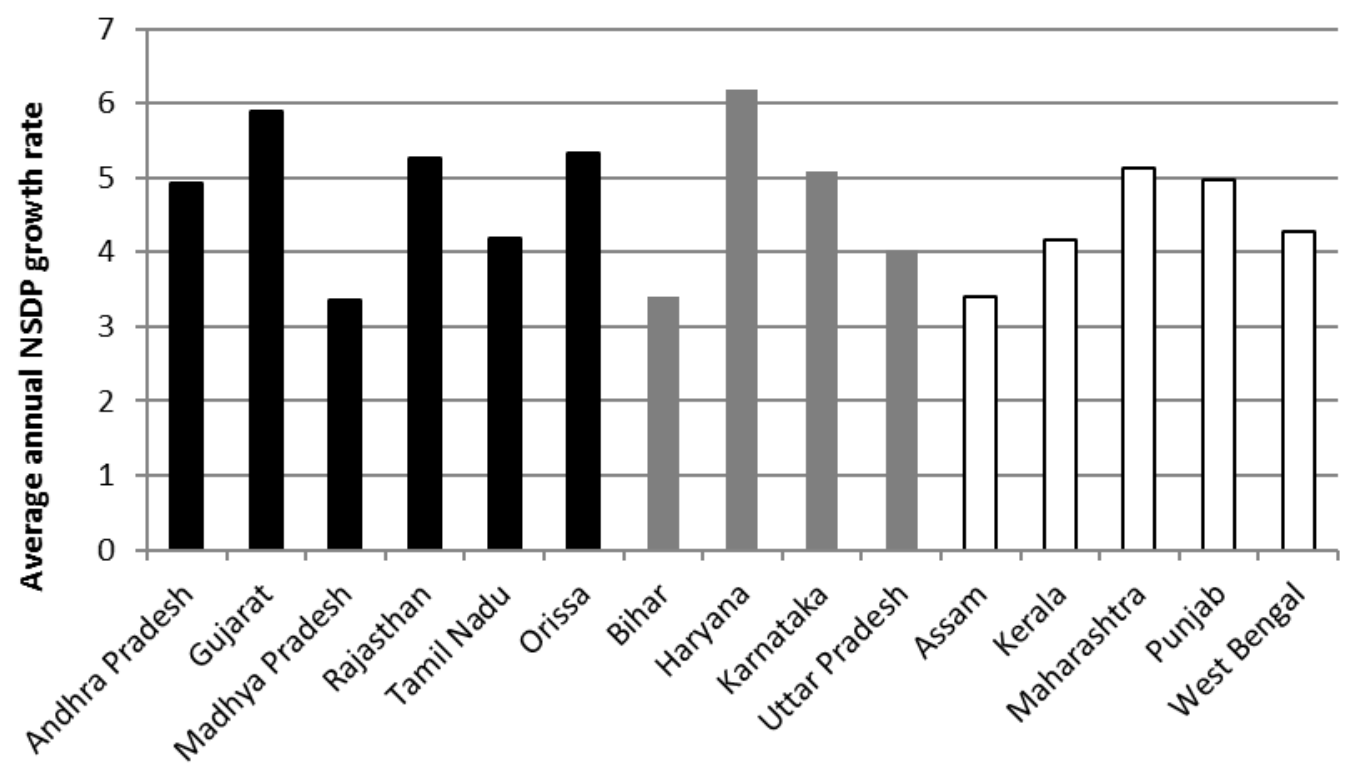

7 Figure 14 - Average growth rates 1961-2007 (the maximum extent of EPW 2009 data),

8 grouped according to Continuously Correlated (black), Decayed Correlation (grey) and Never 9 Correlated (white) 


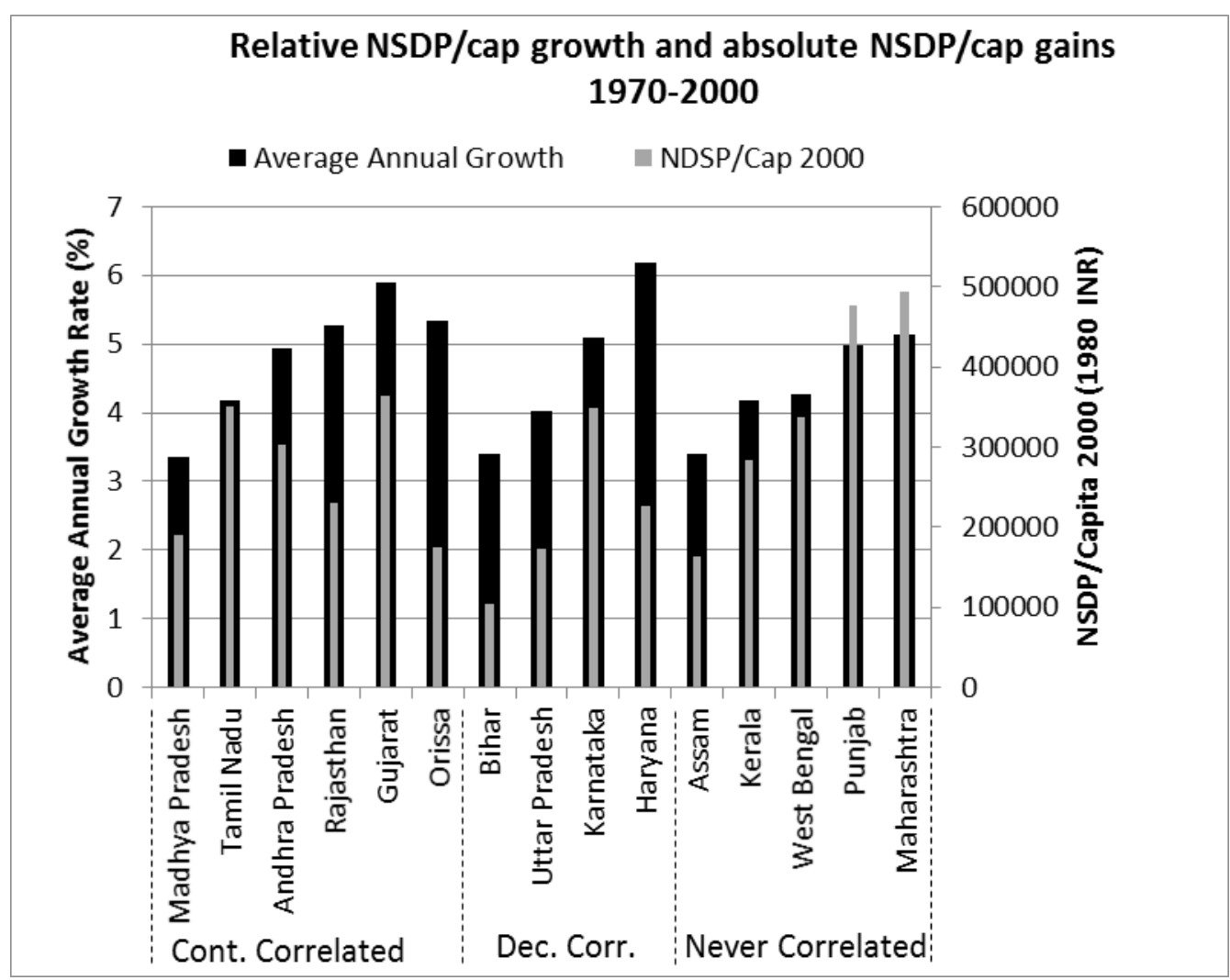

Figure 15 - Combined graph of average annual growth rates and NSDP/Capita in 2000.

Economic Diversification agriculture does not necessarily lessen the impact of rainfall variation on the economy as a whole is also supported by the rainfall-growth analysis, thereby disproving Hypothesis 6 . All states exhibit a large decline in the importance of agriculture. In 1970, diversification away from agriculture might have appeared to be related to buffering from rainfall impact, with non-correlated states having, on average the lowest agricultural composition of the three categories. By 2004/5 however, all three categories of states have a very similar average contribution of agriculture to NSDP of between $23 \%$ and $24 \%$. Of interest, Continuously Correlated states have, on average, the lowest agricultural contribution by 2004/5. The available economic data from the EPW foundation does not include disaggregated information on food processing industries and other economic activities in the food supply chain downstream of growers. If available in the archives, a detailed breakdown of agricultural makeup may enable the propagation of agricultural impacts across the economy. how population purchasing power might be impacted by rainfall variation. However, 
1 employment trends also do not support Hypothesis 6 of diversification as buffering from

2 rainfall. The employment data shows that by 2004/5 Never Correlated states have on average

$348 \%$ in agricultural employment, Decayed Correlation states $66 \%$ and Continuously

4 Correlated 60\%. The state-wise breakdown of employment (along with economic makeup) is

5 given in Table 6. The difference between Never Correlated states and the remainder of the

6 sample is significant (one tailed t-test, $\mathrm{p}=0.048$ ). The fact that Decayed Correlation states

7 have changed their sensitivity to rainfall while maintaining an average of $66 \%$ agricultural

8 employment calls into question the idea that high agricultural employment necessarily

9 propagates hydroclimatic impacts throughout the economy. Bihar, exhibiting statistically

10 Decayed Correlation, had an agricultural population of 76\% in 2004/5, Uttar Pradesh 67\%,

11 Karnataka 64\% and Haryana 55\%. Given the different compositions of the non-agricultural

12 economies across the states, along with different political cultures of the states, it is perhaps

13 not surprising that transmission of agricultural shocks throughout the economy may vary.

14 This observation invites further consideration of context when evaluating investments to

15 buffer growth from rainfall variation.

16

\begin{tabular}{|l|l|l|r|l|}
\hline & & $\begin{array}{l}\text { Agriculture } \\
\text { at 1970/1 } \\
\text { (\% total } \\
\text { NSDP) }\end{array}$ & $\begin{array}{l}\text { Agriculture } \\
\text { at 2004/5 } \\
\text { (\% total } \\
\text { NSDP) }\end{array}$ & $\begin{array}{l}\text { Agricultural } \\
\text { Employment } \\
\text { 2004/5 } \\
\text { (\% total } \\
\text { employment) }\end{array}$ \\
\hline $\begin{array}{l}\text { Andhra } \\
\text { Pradesh }\end{array}$ & $\begin{array}{l}\text { Category } \\
\text { Correlated }\end{array}$ & $54 \%$ & $24 \%$ & $53 \%$ \\
\hline Gujarat & $\begin{array}{l}\text { Continually } \\
\text { Correlated }\end{array}$ & $43 \%$ & $17 \%$ & $62 \%$ \\
\hline $\begin{array}{l}\text { Madhya } \\
\text { Pradesh }\end{array}$ & $\begin{array}{l}\text { Continually } \\
\text { Correlated }\end{array}$ & $56 \%$ & $29 \%$ & $64 \%$ \\
\hline Rajasthan & $\begin{array}{l}\text { Continually } \\
\text { Correlated }\end{array}$ & $62 \%$ & $30 \%$ & $66 \%$ \\
\hline Tamil Nadu & $\begin{array}{l}\text { Continually } \\
\text { Correlated }\end{array}$ & $39 \%$ & $12 \%$ & $46 \%$ \\
\hline Orissa & $\begin{array}{l}\text { Continually } \\
\text { Correlated }\end{array}$ & $59 \%$ & $24 \%$ & $67 \%$ \\
\hline Bihar & $\begin{array}{l}\text { Decayed } \\
\text { Correlation }\end{array}$ & $44 \%$ & $24 \%$ & $76 \%$ \\
\hline Haryana & $\begin{array}{l}\text { Decayed } \\
\text { Correlation }\end{array}$ & $64 \%$ & $25 \%$ & $55 \%$ \\
\hline Karnataka & $\begin{array}{l}\text { Decayed } \\
\text { Correlation }\end{array}$ & $55 \%$ & $19 \%$ & \\
\hline $\begin{array}{l}\text { Uttar } \\
\text { Pradesh }\end{array}$ & $\begin{array}{l}\text { Decayed } \\
\text { Correlation }\end{array}$ & $59 \%$ & $31 \%$ & $64 \%$ \\
\hline
\end{tabular}




\begin{tabular}{|l|l|r|r|r|}
\hline Assam & $\begin{array}{l}\text { Never } \\
\text { Correlated }\end{array}$ & $40 \%$ & $29 \%$ & $71 \%$ \\
\hline Kerala & $\begin{array}{l}\text { Never } \\
\text { Correlated }\end{array}$ & $43 \%$ & $14 \%$ & $40 \%$ \\
\hline Maharashtra & $\begin{array}{l}\text { Never } \\
\text { Correlated }\end{array}$ & $26 \%$ & $13 \%$ & $45 \%$ \\
\hline Punjab & $\begin{array}{l}\text { Never } \\
\text { Correlated }\end{array}$ & $58 \%$ & $36 \%$ & $33 \%$ \\
\hline West Bengal & $\begin{array}{l}\text { Never } \\
\text { Correlated }\end{array}$ & $36 \%$ & $23 \%$ & $49 \%$ \\
\hline & & $52 \%$ & $23 \%$ & $60 \%$ \\
\hline $\begin{array}{l}\text { Continually } \\
\text { Correlated } \\
\text { (average) }\end{array}$ & & $56 \%$ & $25 \%$ & $66 \%$ \\
\hline $\begin{array}{l}\text { Decayed } \\
\text { Correlation } \\
\text { (average) }\end{array}$ & & $41 \%$ & $23 \%$ & \\
\hline $\begin{array}{l}\text { Never } \\
\text { Correlated } \\
\text { (average) }\end{array}$ & & & & $48 \%$ \\
\hline
\end{tabular}

1 Table 6 - State-wise breakdown of agricultural economic contribution (\% annual NSD) and

2 agricultural employment (\% total employment)

3

4 In light of these results, Hypothesis 6 is partially proven, but only for Never Correlated states.

5 The evidence that economic diversification is not related to reduced rainfall sensitivity for

6 Decayed Correlation states provides state level evidence to support the national observations

7 by Virmani (2004). However Virmani’s suggestion that demand side effects propagate

8 rainfall sensitivity through a continued high agricultural employment is challenged by the

9 continued high agricultural employment in Decayed Correlation states. This is especially so

10 in in Karnataka and Uttar Pradesh, where agricultural NSDP remains correlated with rainfall

11 but the total NSDP is no longer correlated. The question of mechanisms of propagation of

12 hydroclimatic impacts across increasingly diversified economies is therefore worthy of

13 further research at state level in India.

6. Conclusions

17 This paper set out to investigate the relationship between economic growth and rainfall across

18 the 15 larger states of India totalling over 920 million people and equivalent to around 12\%

19 of the global population. The paper has further developed the methodology of Grey and 
1 Sadoff (2007) for wider analytical application, and investigated the impact of hydroclimatic

2 variability on India's economy and the pathways by which states may have buffered

3 themselves to hydroclimatic economic risk. In analysing India, a robust methodology has

4 been developed that is effective for a range of economic and geographic contexts that

5 encapsulates much of the global range of geographic and economic water security contexts

6 from dry to flood prone, poor to rich. The work therefore establishes a methodology for

7 analysis of static and changing rainfall-growth relationships using basic datasets with limited

8 transformation. For India, it has identified three statistically robust behaviours: Continuously

9 Correlated economic growth and rainfall variation throughout the available record, Decayed

10 Correlation of economic growth from rainfall variation, and states whose economies are

11 Never Correlated with rainfall variation.

13 The analysis has shown there is a statistically significant relationship between major

14 expansion in irrigation and economies in which the correlation between rainfall variation and

15 economic growth has decayed. Groundwater does not appear to buffer economies from variability, with the most vulnerable states also the most dependent on groundwater. Contrary to the literature at the national scale, this state-wise analysis suggests that correlation of growth with rainfall variability does not appear to retard the average growth rate of economies (although this trend masks very different baselines, including per-capita income levels between states). The finding implies that economic shocks in drought years are countered by robust growth in post-drought years.

Finally, the research has confirmed national trends that diversification of economies away from agriculture does not buffer the economy from drought. Contrary to the literature however, high agricultural employment does not appear to be a determinant of continued economy-wide sensitivity to rainfall variation. Further research into mechanisms by which rainfall events propagate from the agricultural economy to the non-agricultural economy is therefore needed. Additionally, further research is required into sub-state rainfall and economic trends, particularly the role of rainfall location in influencing economic impacts for particular drought and flood events. The unknown impact of spatial variation of effects across states, and the complexity of flood and drought effects invites further research at the sub-state level into how rainfall-growth impacts occur at this finer scale and affect aggregate state-wise 33 results. 
1 While there are noted methodological and data limitations, this paper demonstrates the

2 significance of trends that emerge, and the diversity of behaviours exhibited, across India's

3 states. Statistically robust trends have been identified despite significant internal granularity

4 below the state-level scale of analysis and data uncertainty (including changing economic

5 measurement baselines) that would be expected to mask any relationships. However as the

6 cases of Decayed Correlation have highlighted, it is possible that there are multiple factors

7 explaining the changed relationship in different states. The impact of flooding events has

8 proved challenging to isolate, partly because of limited data, and partly because of the spatial

9 disparity between rainfall and flood occurrence. Importantly, this paper verifies and develops

10 the application of methodologies for assessing past and continuing relationships between

11 rainfall variability and economic growth. The methodology developed can be usefully applied

12 across other national and sub-national cases to explore the relationship between rainfall and

13 economic growth. 


\section{References}

1. Barrios, S., Bertineli, L., and Strobl, E., 2010. Trends in Rainfall and Economic Growth in Africa: A Neglected Cause of the African Growth Tragedy. The Review of Economics and Statistics v92(2) pp350-366. doi:10.1162/rest.2010.11212

2. Bestait, F., 1874. Ce qu'on voit et ce qu'on ne voit pas. Essays on Political Economy by the Late M Frederic Bastait. Provost and Co, London.

3. Bosworth, B., Collins, S. M., Virmani, A., 2007. Sources of Growth in the Indian Research. Cambridge, MA. Available online: http://www.nber.org/papers/w12901

4. Brown, C., Meeks, R., Ghile, Yoi, and Hunu, K., 2013. Is water security necessary? An empirical analysis of the effects of climate hazards on national-level economic growth. Phil Trans R Soc A 371:20120416.

5. Briscoe, J., Grey, D., Sadoff, C., Rosegrant, M., Bhatia, R., 2005. Report of the Goa Retreat on Water and Growth. World Bank, July 25-27 2005 (unpublished, on file).

6. Briscoe, J., and Malik R.P.S., 2006 India's water economy: bracing for a turbulent future. OUP, New Delhi.

7. Brown, C., Lall, U., 2006 Water and Economic Development: The role of Variability and a framework of resilience. Natural Resources Forum, 30(4) 306-317.

8. Cagliarini, A., and Rush, A., 2011. Economic Development and Agriculture in India. Reserve Bank of Australia Bulletin, June Quarter 2011 p.15-22.

9. Carrão, H., Naumann, G., and Barbosa, P., 2016. Mapping global patterns of drought risk: An empirical framework based on sub-national estimates of hazard, exposure and vulnerability. Global Environmental Change 39, p108-124.

10. Centre for Science and Environment (CSE) (online) Average annual rainfall of the states of India. Available online: http://www.rainwaterharvesting.org/urban/rainfall.htm (accessed 31/12/2014)

11. COLA, (online). India Administrative boundaries. Available at: http://www.monsoondata.org/customize/india_polygons.asc

12. Conway, D., and Schipper, E. L. F., 2011. Adaptation to climate change in Africa: Challenges and opportunities identified from Ethiopia. Global Environmental Change 2, p.227-237. 
13. Dadson, Hall, Garrick, Sadoff, Grey, Whittington 2017. Water Security, Risk and Economic Growth: Insights from a dynamical systems model. Water Resour. Research., 53, doi:10.1002/2017WR020640.

14. Dalin, C., Wada, Y., Kastner, T., and Puma, M. J., 2017. Groundwater depletion embedded in international food trade. Nature 543, 30 March.

15. De le Fuente, A., 2013. A mixed splicing procedure for economic time series. BBVA Research Working papers. Madrid, January 2013. https://www.bbvaresearch.com/wpcontent/uploads/migrados/WP_1302_tcm348-364162.pdf

16. De la Escusura, L P. 2014. Mismeasuring Long Run Growth. The Bias form Spliced National Accounts. Working Papers in Economic History, Universidad Carlos III de Madrid. http://earchivo.uc3m.es/bitstream/handle/10016/19340/wp1404.pdf?sequence=1

17. Dee, D. P., Uppala, S. M., Simmons, A. J., Berrisford, P., Poli, P., Kobayashi, S., Andrae, U., Balmaseda, M. A., Balsamo, G., Bauer, P., Bechtold, P., Beljaars, A. C. M., van de Berg, L., Bidlot, J., Bormann, N., Delsol, C., Dragani, R., Fuentes, M., Geer, A. J., Haimberger, L., Healy, S. B., Hersbach, H., Hólm, E. V., Isaksen, L., Kållberg, P., Köhler, M., Matricardi, M., McNally, A. P., Monge-Sanz, B. M., Morcrette, J.-J., Park, B.-K., Peubey, C., de Rosnay, P., Tavolato, C., Thépaut, J.-N. and Vitart, F., 2011. The ERA-Interim reanalysis: configuration and performance of the data assimilation system. Q.J.R. Meteorol. Soc., 137: 553-597. doi:10.1002/qj.828

18. Dinar, A., Mendelsohn, R., Evenson, R., Parikh, J., Sanghi, A., Kumar, D., McKinsy, J., and Lonergan, S., 1998. Measuring the impact of climate change on Indian agriculture. World Bank Technical Paper No. 402. Available online: http://documents.worldbank.org/curated/en/793381468756570727/pdf/multi-page.pdf

19. Dreze J., and Sen. A., 2013. An uncertain Glory: India and Its Contradictions. Penguin, London.

20. EPW Foundation 2009. Domestic Product of States of India : 1960-61 to 2006-07. Mumbai, India 2nd edition (updated)

21. FAO 2013. Food Balance Sheets: India. Available via FAOStat at fao.org

22. Gadgil, S., 2003 The Indian Monsoon and its Variability. Annual Review of Earth and Planetary Sciences 31, p.429-67

23. Gadgil, S., and Gadgil, S., 2006, Thee Indian Monsoon, GDP and Agriculture. Economic and Political Weekly, v.41(47) (Nov.25-Dec.1). pp.4887,4889-4895. 
24. Garrick, D., and Hall, J., 2014. Water Security and Society: Risks, Metrics and Pathways. Annual Review of Environment and Resources. 39 p.611-39

25. GADM 2012. Global Administrative Areas Database. v.2.6 (2012). Downloaded from http://biogeo.ucdavis.edu/data/gadm2/shp/IND_adm.zip via gadm.org in March 2015.

26. Gorst, A., 2017. Assessing Climatic and Technological Constraints to Agricultural Productivity in South Asia. A thesis submitted to the Department of Geography and Environment of the London School of Economics and Political Science for the degree of Doctor of Philosophy, July 2017.

27. Government of India 2013. Central Water commission, Flood Forecast Monitoring Directorate. 'State Wise Flood Damage Statistics - regarding' http://www.cwc.gov.in/main/downloads/FFM.2200-2291.27112012.pdf

28. Grey, D., and Sadoff, C. W., 2007 Sink or Swim? Water security for growth and development. Water Policy 9, 545-571

29. Grey, D., and Sadoff, C.W., (2006). 'Water for Growth and Development' in Thematic Documents of the IV World Water Forum. Comision Nacional del Agua: Mexico City

30. Gulati, A., Meinzen-Dick, R., and Raju, K. V., 2005. Institutional Reforms in Indian Irrigation. IFPRI, Sage Publications, New Delhi.

31. Gulati, M., and Pahuja, S., 2015. Direct delivery of power subsidy to agriculture in India. ESMAP and Sustainable Energy for All. Available online at: http://www.se4all.org/sites/default/files/l/2015/08/SE4AllDirect_Delivery_of_Power_Subsidy_to_Agriculture_in_India.pdf

32. Hall, J. W., Grey, D., Garrick, D., Fung, F., Brown, C., Dadson, S.J. and Sadoff, C., (2014). Water Security: Coping with the curse of freshwater variability. Science 346(6208): 429-430.

33. Harris, I., Jones, P. D., Osborn, T. J., and Lister, D. H., 2014. Updated high-resolution grids of monthly Climatic observations - the CRU TS3.10 Dataset. International Journal of Climatology 34(3) pp623-642.

34. ICRISAT, 2012. Irrigation Extent Data. Available online, accessed via http://vdsa.icrisat.ac.in/vdsa-database.aspx

35. IMF 2016. IMF Executive Board Concludes 2016 Article IV Consultation with the Federal Democratic Republic of Ethiopia. October 4 2016. Press Release No 16/443. Available at: https://www.imf.org/en/News/Articles/2016/10/04/PR16443-EthiopiaIMF-Executive-Board-Concludes-2016-Article-IV-Consultation 
36. Kohli, A., 2006. Politic of Economic Growth in India, 1980-2005: Part II: The 1990s and Beyond. Economic and Political Weekly, V.41(14) (April 8-14 $\left.{ }^{\text {th }}\right)$ pp1361-1370.

37. Lesk, C., Rowhani, P. and Ramankutty, N. 2016. Influence of extreme weather disasters on global crop production. Nature v529 pp.84-87. 7 Jan 2016. Doi 10.1038. 38.

39. Malik, R. P. S., 2016. Falling Water Tables - Sustaining Agriculture. The challenges of groundwater management in India. INDAS - South Asia Working Paper No.17. August 2016. Available online http://www.indas.asafas.kyoto-u.ac.jp/second/wpcontent/uploads/2016/10/INDASWP17.pdf

40. Mulligan, M., 2006. Global Gridded 1km TRMM Rainfall Climatology and Derivatives. Version 1.0. Database: http://geodata.policysupport.org/2b31climatology 41. Mooley, D. A., Parthasarathy, B., Sontakke, N. A., and Munot, A. A., 1981. Annual Rain-Water Over India, Its Variability and Impact on the Economy. Journal of Climatology Vol 1. 167-186.

42. Open Government Data Platform, 2013. Area Weighted Monthly, Seasonal and Annual Rainfall (in mm) for 36 Meteorological Subdivisions. Available online via https://data.gov.in/catalog/area-weighted-monthly-seasonal-and-annual-rainfall-mm36-meteorological-subdivisions\#web_catalog_tabs_block_10 (accessed 20 Feb 2015)

43. Open Government Data Platform 2015. NSDP factor cost Industry Origin 2004-05 prices series. Available via data.gov.in. (accessed December 2015)

44. Open Government Data Platform, 2013b. State-wise Percentage and Number of Persons below Poverty Line for the year 2004-05. Data Compiled by Planning Commission. Available online at https://data.gov.in/resources/state-wise-percentageand-number-persons-below-poverty-line-year-2004-05/download (accessed March 2017)

45. PRS Legislative Research, 2013. Distribution of Employment Sector Wise. Available online http://mla.prsindia.org/sites/default/files/policy_guide/sector\%20wise\%20emp\%20\%2 81\%29.pdf

46. Rai, H., and Pendey, J., 1981. State Politics in Bihar: A Crisis of Political Institutionalisation. The Indian Journal of Political Science 42(4) pp.45-64.

47. Rajeevan, M., Bhate, J., Kale, J.D., and Lal, B., 2006. High Resolution daily gridded rainfall data for the Indian region: Analysis of break and active monsoon spells. Current Science 91(3), 10 August 2006. 
48. Rajeevan, M., Bhate, J., Kale, J. D. and Lal, B., 2005. Development of a high resolution daily gridded rainfall data for the Indian region. Met. Monograph Climatology No. 22/2005. Available online at: http://citeseerx.ist.psu.edu/viewdoc/download?doi=10.1.1.473.8170\&rep=rep1\&type= pdf

49. Reserve Bank of India, 2014. Handbook of Statistics on the Indian Economy Table 5: Net State Domestic Product at Factor Cost - State-Wise (At Constant Prices) https://www.rbi.org.in/scripts/PublicationsView.aspx?id=15795

50. Row, V. M., and Hiremath, K. C., 2009. Agricultural and Rural Development: Preparing for the Challenges Ahead. In Singh, S., and Reddy, V. R., Changing Contours of Asian Agriculture: Policies, Performance and Challenges. Academic Foundation ,New Delhi. p.93-138.

51. Sadoff, C. W., et al.,2015. Securing Water, Sustaining Growth: Report of the GWP/OECD Task Force on Water Security and Sustainable Growth, University of Oxford, UK.

52. Shah, T., 2009. Taming the Anarchy: Groundwater governance in South Asia. RFF Press, Washington DC

53. Sinha, A., and Tejani, S., 2004. Trend Break in India’s GDP Growth Rate; Some Comments. Economic and Political Weekly, v.39(52) (Dec 25-31) pp.5634-5639

54. Skidmore, M., and Toya, H., 2002. Do Natural Disasters Promote Long-Run Growth? Economic Enquiry 40(4). pp664-687.

55. Skroupa, C. P. 2016. Mitigating Water Risk: The Business Impact. 23 Feb. Forbes.com. http://www.forbes.com/sites/christopherskroupa/2016/02/23/mitigatingwater-risk-the-business-impact/\#3a5d674934a8

56. Virmani, A., 2004. Economic Reforms: Policy and Institutions Some Lessons from Indian Reforms. Working Paper No. 121. Indian Council for Research on International Economic Relations. New Delhi.

57. Virmani, A., 2006. India’s Economic Growth History: Fluctuations, Trends, Break Points and Phases. Indian Economic Review, New Series, Vol. 41(1) (Jan-June) pp.81103. Department of Economics, Delhi School of Economics.

58. Wang, B., 2006. The Asian Monsoon. Praxis Press, Chichester

59. World Bank 2006. Ethiopia: Managing Water Resources to Maximise Sustainable Growth. A World Bank Water Resources Assistance Strategy for Ethiopia. World Bank Agriculture and Rural Development Department. Washington DC. 